\title{
Changes in land use/cover mapped over 80 years in the Highlands of Northern Ethiopia
}

\author{
ETEFA Guyassa ${ }^{1,2}$, Amaury FRANKL ${ }^{1,3}$, Sil LANCKRIET', \\ BIADGILGN Demissie ${ }^{1,4}$, GEBREYOHANNES Zenebe ${ }^{5}$, AMANUEL Zenebe ${ }^{2}$, \\ Jean POESEN ${ }^{6}$, Jan NYSSEN ${ }^{1}$ \\ 1. Department of Geography, Ghent University, Belgium; \\ 2. Department of Land Resources Management and Environmental Protection, Mekelle University, Ethiopia; \\ 3. Research Foundation Flanders (FWO), Brussels, Belgium; \\ 4. Department of Geography and Environmental Studies, Mekelle University, Ethiopia; \\ 5. Institute of Geo-information and Earth Observation Sciences, Mekelle University, Ethiopia; \\ 6. Division of Geography, Department of Earth and Environmental Sciences, KU Leuven, Belgium
}

\begin{abstract}
Despite many studies on land degradation in the Highlands of Northern Ethiopia, quantitative information regarding long-term changes in land use/cover (LUC) is rare. Hence, this study aims to investigate the LUC changes in the Geba catchment $\left(5142 \mathrm{~km}^{2}\right)$, Northern Ethiopia, over 80 years (1935-2014). Aerial photographs (APs) of the 1930s and Google Earth (GE) images (2014) were used. The point-count technique was utilized by overlaying a grid on APs and GE images. The occurrence of cropland, forest, grassland, shrubland, bare land, built-up areas and water body was counted to compute their fractions. A multivariate adaptive regression spline was applied to identify the explanatory factors of LUC and to create fractional maps of LUC. The results indicate significant changes of most types, except for forest and cropland. In the 1930s, shrubland (48\%) was dominant, followed by cropland (39\%). The fraction of cropland in $2014(42 \%)$ remained approximately the same as in the 1930 s, while shrubland significantly dropped to $37 \%$. Forests shrank further from a meagre $6.3 \%$ in the 1930 s to $2.3 \%$ in 2014 . High overall accuracies (93\% and $83 \%$ ) and strong Kappa coefficients $(89 \%$ and $72 \%)$ for point counts and fractional maps respectively indicate the validity of the techniques used for LUC mapping.
\end{abstract}

Keywords: fractional map; Google Earth; land use/cover; multivariate adaptive regression; Italian aerial photographs

\section{Introduction}

Land use/cover (LUC) has transformed (on different spatial scales) across the world (Lambin et al., 2003; Lepers et al., 2005; Maitima et al., 2009; FAO, 2010), including Ethiopia (Alemayehu et al., 2009; Asmamaw et al., 2011; Mengistu et al., 2012; Meire et al., 2013; de Muelenaere et al., 2014). At global and regional scales, an increase of the cropland area has been a common phenomenon at the expense of the forest and shrubland area during the last few centuries (Ramankutty and Foley, 1999; Goldewijk, 2001; Goldewijk and

Received: 2017-04-12 Accepted: 2017-09-13

Author: Etefa Guyassa, PhD, specialized in physical geography. E-mail: etefag@gmail.com 
Ramankutty, 2004). In Northern Ethiopia, severe land degradation occurred until the large-scale implementation of soil and water conservation (SWC) measures, that started in circa 1991 (Nyssen et al., 2004; Frankl et al., 2011; Hurni and Wiesmann, 2010). Forests which once covered large country areas vanished, although there are no reliable data on the original forest cover, about which many speculations exist (Pankhurst, 1995; Woien, 1995).

The explanation of the causes of land use/cover change extends from simple to multiple factors and their complex interactions occur on different spatial and temporal scales (Lambin et al., 2001). The rapid population growth, changing economic conditions and institutional factors, local and global uses are identified as the main factors for the transformation of the earth's surface on a global scale (Turner et al., 1994; Lambin et al., 2003; Lambin et al., 2001). The agriculture-based economy (Nyssen et al., 2004), low income (Kidane et al., 2010; FAO, 2011), rapid population growth (CSA, 2008) and recurrent drought occurrences are assumed to be the prominent drivers for land cover changes in the Tigray region, Northern Ethiopia.

Despite the presence of ancient human settlements and agricultural practices in Northern Ethiopia (Bard et al., 2000; Nyssen et al., 2004), the long-term evolution of change in LUC has received a little attention in the region, particularly on a local scale. Most often, surface processes (LUC change, gully erosion, surface runoff and implementation of soil and water conservation) have occurred at large spatial and temporal scales in Northern Ethiopia (Hurni et al., 2005). Although some studies on LUC change are available in the region (e.g. Munro et al., 2008; Alemayehu et al., 2009; Teka et al., 2013; de Muelenaere et al., 2014), they all cover the period from 1965 to 2014 and generally focus on small catchments. Nyssen et al. (2009) and Meire et al. (2013) have compared the land use type and environmental changes in the region by using repeated historical terrestrial photographs over 140 years (from 1868 to 2008). Despite the wide application of terrestrial photographs for the study of LUC changes, the inaccessibility of remote sites constrains the spatial representation of terrestrial photographs as compared to aerial photography and satellite images.

Earlier reports on land cover, e.g. vegetation cover, are based on subjective descriptions and cause inconclusive reports on the original cover and deforestation rate in Ethiopia (Woien, 1995). In this regard, the shortage of historical datasets on LUC is claimed as a problem to measure the long-term environmental changes. Although the 1930s Aerial Photographs (APs), which are the oldest aerial photographs of the region taken during the Italian occupation of Ethiopia (1935-1941) (Nyssen et al., 2016), are available, they have rarely been used to compare the historical LUC with the current situation. An exception to that is the local study by Frankl et al. (2015). These Italian aerial photographs are important historical datasets for spatio-temporal analyses of land use, cover and management (Nyssen et al., 2016). Aerial photographs taken for military purposes during the World War II have been widely used for civilian purposes, such as land use change studies (Zeimetz et al., 1976).

Long-term data are required for reliable LUC change assessments and quantifications (Lambin et al., 2003). A good knowledge of historic land use trends with adequate coverage is important so as to understand the current and future developments (Goldewijk, 2001). A better understanding of the distribution of LUC allows reliable predictions and improves the scenario of future environmental changes (Lambin et al., 2003). Large-scale LUC changes can have substantial biophysical consequences and influence the water balance of a catch- 
ment, which in turn determines the economic development activities (e.g. dam construction, ground water use) in the area. Moreover, the map of LUC on the scale of the Geba catchment (ca. $5142 \mathrm{~km}^{2}$ ), Northern Ethiopia, particularly in the $1930 \mathrm{~s}$, is very important for the analysis of environmental changes over a long period. The Geba catchment is characterized by diversified biophysical elements. Hence, the study area was selected due to its representativeness for the Northern Ethiopian Highlands in terms of its biophysical characteristics (i.e. climate, geology, soils, topography and LUC). Therefore, this study aims: 1) to quantify the long-term LUC changes of the Geba catchment $\left(5142 \mathrm{~km}^{2}\right)$, Northern Ethiopia, by comparing the areal fractions of different LUC classes on the oldest aerial photographs (1935-1936) to the Google Earth images of 2014; 2) to analyze the major explanatory factors, which determine the LUC occurrence in the two periods, and 3) to create fractional maps of the major LUC of the Geba catchment in the 1930s and in 2014.

\section{Materials and methods}

\subsection{Study area}

The study area, the Geba catchment (Figure 1), is located in the Tigray region, Northern Ethiopian Highlands, between $13^{\circ} 16^{\prime}$ to $14^{\circ} 15^{\prime} \mathrm{N}$ and $38^{\circ} 38^{\prime}$ to $39^{\circ} 48^{\prime} \mathrm{E}$. The topography of the catchment was obtained from the DEM-SRTM data with a $30 \mathrm{~m} \times 30 \mathrm{~m}$ resolution (USGS, 2016). It covers an area of $5142 \mathrm{~km}^{2}$ with elevations ranging from about $900 \mathrm{~m}$ a.s.l. at its outlet in the southwest to $3300 \mathrm{~m}$ a.s.l. near Adigrat in the north. The Geba River is one of the major tributaries of the Tekeze River which finally joins the Atbara River and the Nile in Sudan (Figure 1).

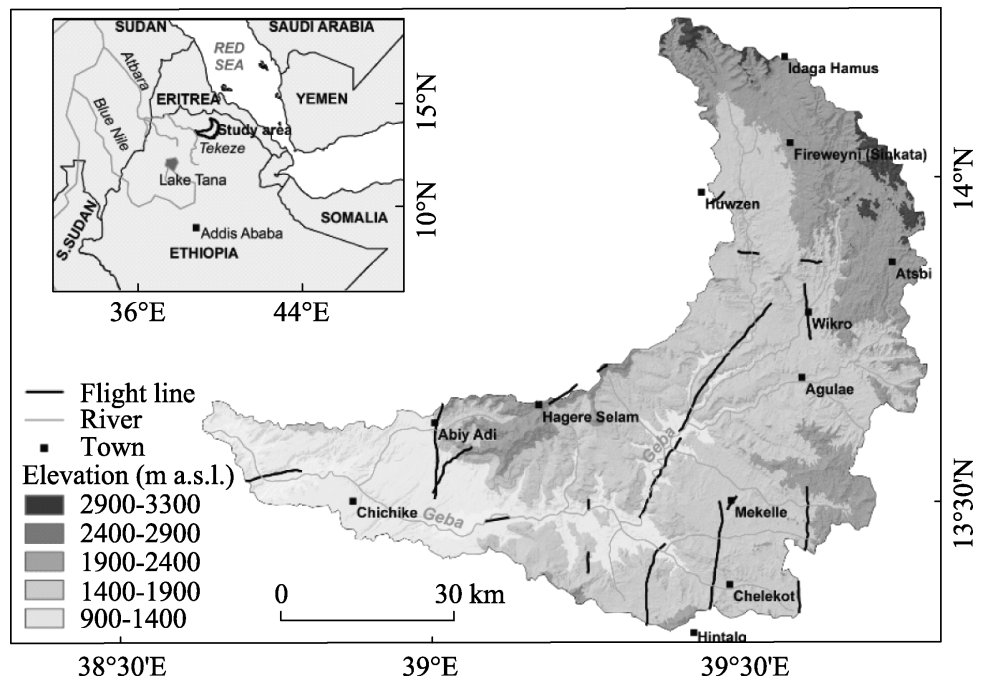

Figure 1 Oro-hydrography of the Geba catchment and flight lines of Italian aerial photographs

The Geba catchment is characterized by a diversified geology: Precambrian basement, Palaeozoic and Mesozoic sedimentary rocks, Tertiary volcanic rocks and Quaternary deposits (Tesfamichael et al., 2010). A larger part of the catchment (55\%) is classified as sloping $(6 \%-15 \%)$ and over $30 \%$ is steep $(>15 \%)$ while most of the flat areas are found around Mekelle, Wukro, Sinkata and Atsbi accounting for only about 15\% (Tielens, 2012). Lithologic 
Lithologic and topographic relations are very important factors for explaining the soil type distribution (Van de Wauw et al., 2008; Tielens, 2012). The dominant soils of the catchment include Leptosols, Cambisols and Regosols, with the most developed and deepest soil types on gentle slopes (Vertisols, Luvisols, Cambisols) (Nyssen et al., 2008a; Tielens, 2012). Soil erosion, landslide and deposition processes in the catchment result in the formation of young soils particularly on foot slopes (HTS, 1976; Nyssen et al., 2008a; Van de Wauw et al., 2008). On steep slopes and plateaus, shallow soils (like Leptosols) and bare rock are found, while more fine-textured soils with alluvial, stagnic or vertic properties are found in the valley bottoms (Tielens, 2012).

The Geba catchment has a tropical and semi-arid climate with a bi-annual rainfall distribution ("belg" = small rain and "kremt" = main rain season). The main rainy season, which accounts for circa $80 \%$ of the annual precipitation is short, restricted to mid-July - early September, but is characterized by intense showers and large drop sizes (Nyssen et al., 2005; Virgo and Munro, 1978). The rainfall is highly variable with an annual depth of 555-1200 $\mathrm{mm}$. It is mainly determined by topographical factors such as slope aspect, aspect of the valley and slope gradient over longer distances (Nyssen et al., 2005), but lacks a significant correlation to elevation (Amanuel, 2009; Gebresamuel et al., 2010; Nyssen et al., 2005; Taye et al., 2013; Vanmaercke et al., 2014; Virgo and Munro, 1978). The annual evapotranspiration depth exceeds the precipitation depth, except during the rainy season, ranging from 905 to $2538 \mathrm{~mm}$ (Hadush, 2012). The mean annual maximum average air temperature ranges from 21 to $31^{\circ} \mathrm{C}$ and the mean annual minimum air temperature ranges from 3 to $16^{\circ} \mathrm{C}$ (Araya et al., 2010) whereas the monthly average varies between 12 and $19^{\circ} \mathrm{C}$.

The economy of the rural communities ( $85 \%$ of population) depends on agriculture, hence cropland dominates land use followed by bushland and bare land (Amanuel, 2009; Gebresamuel et al., 2010; Taye et al., 2013). Rangeland is mainly found on steep slopes and severely degraded due to overgrazing. The study area lost its native forests a long time ago (Aerts et al., 2016; Gebru et al., 2009; Nyssen et al., 2004) and the remnant patches of forests are usually limited to inaccessible areas and around churches (HTS, 1976; Munro et al., 2008; Gebru et al., 2009; Aerts et al., 2016). Over the last century, the Tigray region (including the study area) has faced various man-made and natural problems at different times. The war (by the Italian) in the 1930s in which chemical weapons were used, famines and population displacement due to the drought and civil war (1974-1991) (Lanckriet et al., 2015) and the peak land degradation from the 1930s to the second half of the 20th century (Nyssen et al., 2015) were among the major shocks which took place in the region. Over the last few decades, massive soil and water conservation activities including afforestation had been organized in Northern Ethiopia in order to reverse the environmental degradation (Nyssen et al., 2004; Descheemaeker et al., 2006a; Vancampenhout et al., 2006; Munro et al., 2008; Nyssen et al., 2008b; Frankl et al., 2011, 2013a; Taye et al., 2013).

\subsection{Land use/cover analysis by the point counting method}

Despite its obvious importance for the study of land use, the 1930s photography, which represent the oldest APs of Ethiopia remain underutilized in Ethiopia (Frankl et al., 2015; Nyssen et al., 2016), mainly due to their recent rediscovery. The Italian Military Geographical Institute (IGM) took these black and white APs with a scale ranging from 1:11,500 
(nearly vertical photograph) to 1:13,000-1:18,000 (oblique photographs) during the Italian occupation of Ethiopia (1930s-1940s) and the sets were recovered by Nyssen et al. (2016). These APs cover large areas of Northern Ethiopia, including parts of the Geba catchment except the eastern and northern parts of the catchment.

Due to the obliqueness of these photographs and small areas covered by the stereo pairs of the vertical photographs, creating orthophotographs from these photographs using the conventional photogrammetry method is difficult to apply on large regions (Frankl et al., 2015). Alternatively, the point counting approach allows to extract information easily and to estimate the fractions of LUC from the APs as applied by e.g. Bellhouse (1981) and Daniels et al. (1968). In this technique, different land covers that occur under the points of a grid superimposed on an area are being identified and counted (Bellhouse, 1981). This technique has been chosen for resource assessment and to examine land cover and use changes (Saebo, 1983; Shockey, 1969; Zeimetz et al., 1976). Hence, we applied this point counting technique to Italian aerial photographs to assess the fraction of LUC in 1935-36, while the LUC data in 2014 were obtained from Google Earth imageries captured in the same season (December to February) as the APs. The Google Earth images of the study area for the period from December 2013 to February 2014 are based on Pleiades 1A and Pleiades 1B satellites (2 m resolution) and SPOT 6 satellite (1.5 $\mathrm{m}$ and $6 \mathrm{~m}$ resolution).

To assess LUC, a point grid with 270 points $(18 \times 15$ points $)$ with a spacing of circa $130 \mathrm{~m}$ between the points (Figure 2) was superimposed on the scanned vertical and one oblique AP and GE whose area ranges from $2.39 \mathrm{~km}^{2}$ to $12.36 \mathrm{~km}^{2}$ with an average area of $4.66( \pm 1.72)$ $\mathrm{km}^{2}$. The size and location of GE is approximately the same as the APs. In total, 134 aerial photographs, which cover about $12 \%$ of the study area, taken along 15 flight lines fairly distributed over the study area were used (Figure 1). To cover the northern and eastern part of the study area where APs do not exist (Figure 1), five additional locations were selected where data were available for LUC in 1965 for Dergajen, Hadnet and Sinkata (Teka et al.,

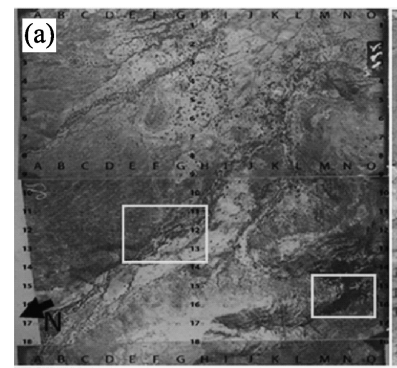

(c)

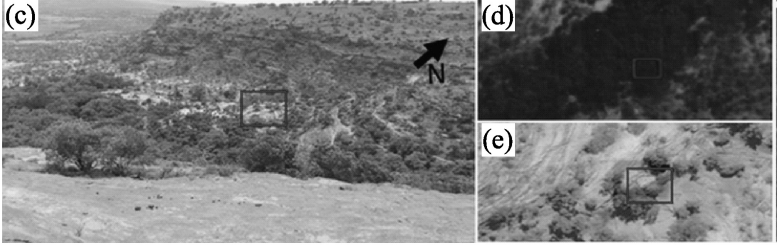

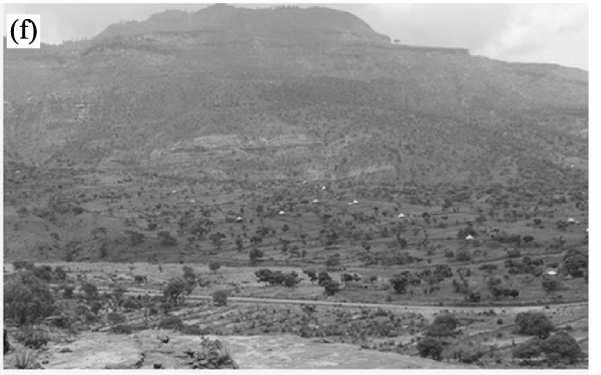

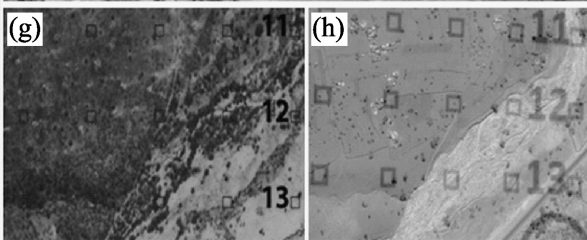

Figure 2 An example of a point grid superimposed on: a) aerial photograph of January 3, 1936 with coordinate of center of vertical photo $13.561547^{\circ} \mathrm{N}$ and $39.024014^{\circ} \mathrm{E}$ (i.e. south of Abiy Adi); b) Google Earth image of January 4, 2014. Significant conversion of LUC occurred at this location as shown by: c) terrestrial photo around grid point N16 where land cover changed from dense forest in 1936 (d) to open forest in 2014 (e), and f) terrestrial photo around grid point F12 where land cover changed from open forest in 1936 (g) to cropland with trees in 2014 (h) 
2015) and for upper Agulae watershed (Alemayehu et al., 2009) and known (permanently forested) places in Dessa'a throughout the 20th century. We assumed that the 1965 interpretation was the best (though not perfect) supplement for the missing Italian APs of that area, while the error of using the 1965's information for the 1930s LUC condition is assumed to be small. Hence, sample locations were well represented by the dominant agro-ecological zones and lithologies of the study area as shown in Supplementary Figure S1.

LUC categories on APs and GE were counted on the screen by three experts. The experts had to count different APs and GE in order to do the point counting in a relatively short time. Seven common LUC classes, forest, shrubland, cropland, grassland, bare lands, water bodies and built-up areas are considered in this study (Table 1). Important photo interpretation elements such as pattern, shape, association, tone and location of LUC were used to count each LUC (Loelkes et al., 1983). Keys were prepared for this counting (Supplementary Table S1)

\subsection{Explanatory factors for land use/cover changes}

Climatic variations, geomorphic settings and socio-economic effects are among the major explanatory factors of LUC occurrences. Northern Ethiopia is characterized by a large climatic and biophysical heterogeneity. Potential environmental factors believed to influence the LUC occurrences and changes in the Geba catchment are climate (precipitation, air temperature, evapotranspiration) and topography (elevation, slope), lithology and soil types. Despite the availability of long-term climate data at meteorological stations in and nearby the study area, a further analysis regarding the effects of climate variables on the distribution of LUC is not done in this study as the interpolation of the point meteorological data resulted in large errors due to strong topographic effects on the rainfall distribution. Other existing databases for spatial rainfall data (e.g. Rainfall Estimate (RFE), from the National Oceanic and Atmospheric Administration Climate Prediction Centre (NOAA-CPC)) was checked if it can be used but the validation of this database using the meteorological stations has resulted in a weak correlation $\left(R^{2}=0.38, n=15\right)$. But climatic variables used as explanatory factors have a strong correlation with topography (such as elevation and slope).

In order to analyze the effect of lithology on LUC distribution, the detailed classification of the catchment was grouped into four major lithological categories based on their mineral composition and physical properties (Table 1). The soil map of the study area produced by Tielens (2012) was used for this study by grouping the soils into three major classes based on their suitability for crop production or plant growth (Supplementary Figure S2a and Table 1). This suitability classification was done using the soil structure, soil drainage and depth characterization of each soil unit (Tielens, 2012).

Socio-economic variables which anticipate to influence the LUC occurrence are mapped for the Geba catchment and are to be used in the LUC modelling. Population density, distance to main roads and distance to towns are the variables used to investigate if socio-economic factors are affecting LUC occurrences. The population density map for 2014 at $1 \mathrm{~km}$ grid was extracted from the Centre for International Earth Science Information Network (CIESIN, 2016). Mapping the distance of cells to main roads and towns in 2014 was based on the Google Earth database (January 10, 2014), while the map of distance to towns in the 1930s was created based on the1930s topographic maps of the study area (IGM, 2012) (see Supplementary Figure S3). 
Table 1 Variables and their descriptions

\begin{tabular}{|c|c|c|c|}
\hline Factor & Variable & Description & Source/reference \\
\hline \multirow{7}{*}{$\begin{array}{l}\text { Land } \\
\text { use/cover }\end{array}$} & Bare land & Land with no vegetation cover, rock outcrop, quarry & WBISPP, 2003 \\
\hline & Built-up area & Land under settlement, roads & \\
\hline & Cropland & $\begin{array}{l}\text { Cultivated land (irrigated and non-irrigated) including open } \\
\text { and regularly ploughed with or without shrub or tree line } \\
\text { (boundary) and scattered trees, fallow with and without } \\
\text { bushes/trees }\end{array}$ & \\
\hline & Forest & $\begin{array}{l}\text { Land covered with dense trees or open; woodland; riparian } \\
\text { trees, plantation (large scale and woodlot), church forest }\end{array}$ & \\
\hline & Grassland & Land covered with grasses used as grazing area & \\
\hline & Shrubland & $\begin{array}{l}\text { Land covered with bushes: open, open with trees, dense, } \\
\text { dense with trees, exclosures }\end{array}$ & \\
\hline & Water body & $\begin{array}{l}\text { Land covered with water: lake, pond, river including dry } \\
\text { river bed }\end{array}$ & \\
\hline \multirow[t]{2}{*}{ Topography } & Alt (m a.s.1.) & Average elevation at different locations & $\begin{array}{l}\text { DEM-SRTM at } 30 \times \\
30 \mathrm{~m} \text { resolution }\end{array}$ \\
\hline & Slope $(\%)$ & Average slope gradient at different locations. & $\begin{array}{l}\text { DEM-SRTM at } 30 \\
\times 30 \mathrm{~m} \text { resolution }\end{array}$ \\
\hline \multirow[t]{3}{*}{ Soil type } & SS & $\begin{array}{l}\text { Soils suitable for cultivation, well to perfectly drained, } \\
\text { fertile, moderately deep to deep soil. e.g. Vertic Cambisols, } \\
\text { Calcaric Vertisols, Vertic Phaeozems }\end{array}$ & $\begin{array}{l}\text { Tielens et al. } \\
(2012)\end{array}$ \\
\hline & SMS & $\begin{array}{l}\text { Soils moderately suitable for cultivation, shallow to moder- } \\
\text { ately deep, moderate fertility, moderately drained. e.g. Eu- } \\
\text { tric Regosols, Eutric Cambisols, Calcic Luvisols, Calcaric } \\
\text { Cambisols }\end{array}$ & \\
\hline & SNS & $\begin{array}{l}\text { Soils not suitable for cultivation, very shallow, rock out- } \\
\text { crop, stony, excessively or poorly drained. e.g. Leptosols, } \\
\text { Gleysols }\end{array}$ & \\
\hline \multirow[t]{4}{*}{ Lithology } & LV & $\begin{array}{l}\text { Volcanics (intrusive and extrusive): trap series; Mekelle } \\
\text { dolerite. Contain wide range of minerals, which enhance } \\
\text { growth of tree and crop }\end{array}$ & $\begin{array}{l}\text { Tesfamichael et al. } \\
\text { (2010); Tesfaye and } \\
\text { Gebretsadik (1982) }\end{array}$ \\
\hline & LSC & $\begin{array}{l}\text { Sedimentary rock dominated by calcium carbonate: metali- } \\
\text { mestone; Antalo limestone; Agula shale. The land has a dry } \\
\text { aspect because of karst and high infiltration. }\end{array}$ & \\
\hline & LSNC & $\begin{array}{l}\text { Sedimentary rocks (non-carbonate): slates, metavolcanics; } \\
\text { Edaga Arbi glacials; alluvium. Fine-texture, results in slow } \\
\text { infiltration and relatively fertile soils }\end{array}$ & \\
\hline & LSS & $\begin{array}{l}\text { Sandstones: metaconglomerate; major intrusive (these are } \\
\text { granites); Enticho sandstone; Amba Aradom sandstone; } \\
\text { Adigrat sandstone. These rocks have coarse texture, silica } \\
\text { dominated. Sandy weathering materials where water will } \\
\text { easily infiltrate; the domination of Si further makes that few } \\
\text { minerals are available for vegetation growth }\end{array}$ & \\
\hline \multirow{3}{*}{$\begin{array}{l}\text { So- } \\
\text { cio-economy }\end{array}$} & $\mathrm{Pd}\left(\# / \mathrm{km}^{2}\right)$ & Population density in 2010 & CIESIN, 2016 \\
\hline & DT $(\mathrm{km})$ & $\begin{array}{l}\text { Distance to town in the } 1930 \text { s (DT30 and distance to town } \\
\text { in } 2014 \text { (DT14) }\end{array}$ & \\
\hline & DR14 $(\mathrm{km})$ & Distance to road in 2014 & \\
\hline
\end{tabular}

\subsection{Accuracy assessment of the point counting method and spatial map}

An accuracy assessment was necessary so as to evaluate the validity of points counted from APs and GE images. Confusion (error) matrixes (Congalton et al., 1983; Hoffer, 1975) were prepared for the point counting and the fractional mapping accuracy measurements (Table 2). For the accuracy assessment of the point counting 275 ground control points that correspond to the points counted on APs/GE were randomly selected from 55 APs (i.e. 3-7 points per photo) and used for verification of both the 1930s and 2014 LUC. For the 1930s LUC, the 
verification was done based on the information obtained from old people who have lived in the area and have information on the historical LUC (from their parents). For 2014, field observations were made to validate whether the different LUC types were correctly identified on the screen. The assessment of accuracy of the fractional maps of the dominant LUC of the study area was done using the Google Earth image (Fritz et al., 2009; Bastin et al., 2013; Annys et al., 2016). Using the $2 \mathrm{~km} \times 2 \mathrm{~km}$ grid, 233 points have been randomly selected utilizing ArcMap from the map of the Geba catchment. Then the values of the different LUC maps of 2014 corresponding to the random points were extracted. Based on these values the dominant LUC at each random point was selected and contrasted to the dominant LUC in the corresponding point in the fractional maps. The same random points were overlaid on the $2014 \mathrm{GE}$ image so as to count the classes that were correctly allocated on the map. The dominant LUC in the random point corresponds to a $1.5 \mathrm{~km} \times 1.5 \mathrm{~km}$ pixel on the fractional map, while the observation on GE was just at a point which can result in the error of disagreement by selecting the non-dominant class. An accuracy check for the historical LUC map could not be made as no field database exists.

Table 2 Commission-omission error matrix of LUC point count and mapping

\begin{tabular}{|c|c|c|c|c|c|c|c|}
\hline \multicolumn{8}{|c|}{ Ground control / Google Earth } \\
\hline & & Cropland & Shrubland & Forest & $\begin{array}{l}\text { Other } \\
\text { cover }\end{array}$ & Sum & $\begin{array}{c}\text { Commission } \\
\text { error }\end{array}$ \\
\hline \multirow{8}{*}{$\begin{array}{l}\text { LUC count } \\
\text { on screen }\end{array}$} & Cropland & 132 & 1 & 0 & 2 & 135 & 0.02 \\
\hline & Shrubland & 6 & 88 & 3 & 2 & 99 & 0.13 \\
\hline & Forest & 0 & 0 & 6 & 0 & 6 & 0.00 \\
\hline & Other & 3 & 2 & 0 & 30 & 35 & 0.10 \\
\hline & Sum & 141 & 91 & 9 & 34 & 275 & \\
\hline & Omission error & 0.06 & 0.03 & 0.33 & 0.12 & & \\
\hline & Overall accuracy & & & & & 0.93 & \\
\hline & Kappa coefficient & & & & & 0.89 & \\
\hline \multirow{8}{*}{$\begin{array}{l}\text { LUC } \\
\text { map }\end{array}$} & Cropland & 106 & 10 & 1 & 6 & 123 & 0.16 \\
\hline & Shrubland & 12 & 68 & 1 & 1 & 82 & 0.21 \\
\hline & Forest & 1 & 1 & 3 & 0 & 5 & 0.67 \\
\hline & Other & 4 & 2 & 0 & 17 & 23 & 0.35 \\
\hline & Sum & 123 & 81 & 5 & 24 & 233 & \\
\hline & Omission error & 0.14 & 0.16 & 0.40 & 0.29 & & \\
\hline & Overall accuracy & & & & & 0.83 & \\
\hline & Kappa coefficient & & & & & 0.72 & \\
\hline
\end{tabular}

\subsection{Data analyses}

The fractions of the LUC classes, described as the density or weight of LUC, were calculated for each scene (AP and GE) as the ratio of the total number of points for each class to the total number of points of all LUC counted per AP/GE (Daniels et al., 1968). Points where the LUC is unknown or invisible on APs due to the clouds or damage of the photographs were excluded from further analyses and the corresponding points on GE omitted, 
too. The significance of the differences in the fraction of each LUC type between the 1930s and 2014 were tested by using the Mann-Whitney $U$ test $(\alpha=0.05)$, while the significance in the frequency of spatial distribution of LUC across the sample area (scene) was checked by using the Chi-square test $(\alpha=0.05)$. The spatial distribution of LUC refers to the binary description of the LUC occurrence (i.e absence or presence) in the sample scene. A change matrix was prepared between LUC in the 1930s and 2014 so as to analyze the transformation of LUC in 2014 as compared to the 1930s.

Rasters of the selected explanatory factors with a resolution of $1.5 \mathrm{~km} \times 1.5 \mathrm{~km}$ were used in order to fit approximately to the scale from which the LUC data were obtained from the APs and GE images (ca. $4.66 \mathrm{~km}^{2}$ ). This grid size was selected based on the smallest scene $\left(2.4 \mathrm{~km}^{2}\right)$, so that all observations have at least 1 cell. Average values of different explanatory factors at the location of all scenes were extracted from their spatial maps created for the Geba catchment. After checking the non-linear relation (using multiple linear regression) between LUC and the explanatory factors, Multivariate Adaptive Regression Splines (MARS) (Friedman, 1991), a non-parametric regression was used to model the LUC classes. It is a stepwise (forward and backward pass) method and a powerful and flexible non-parametric regression for modelling the complex multivariate datasets (Friedman, 1991) widely applied in various disciplines including the LUC change studies (e.g. Quiros et al., 2009; Tayyebi and Pijanowski, 2014). It uses the basis functions as predictors in place of the original data by breaking the data into different regions for fitting. The generalization of the model is checked using the Generalized Cross Validation (GCV) and by its normalized value $\left(\mathrm{GCV} R^{2}\right)$ statistics which are also used to avoid over-fitting training data (Friedman and Silverman, 1989). The relative importance of the explanatory variables is ranked using the three criteria method of the MARS model (number of subset, GCV and RSS) which varies for different LUCs (Table 4).

The MARS equations developed for different LUC types in the 1930s and 2014 were used to create fractional maps of the LUCs, using pixel size of $1.5 \mathrm{~km} \times 1.5 \mathrm{~km}$ that are approximately the same size as the smallest scene area $\left(2.4 \mathrm{~km}^{2}\right)$ of the interpreted APs. In a fractional map, for every pixel, the fraction $(0.00-1.00)$ or the percentage $(0 \%-100 \%)$ of a particular LUC class is represented (Romanov et al., 2003).

Point count and mapping of LUC were validated by computing the commission errors (measure of the producer's accuracy), the omission error (measure of the user' accuracy) and overall accuracy from the error matrix table (Hoffer, 1975; Congalton et al. 1983). Furthermore, the degree of agreement between the accuracy of the counting and the field observation and between the mapping and Google Earth was measured by computing the Kappa coefficient of agreement from the confusion matrix (Fleiss, 1971; Stehman, 1997). This coefficient is used for the correction of the chance (expected) agreement. The multiple Kappa coefficient, i.e. the Fleiss Kappa coefficient, was applied by taking into account the multiple random points and the different LUC classes used for this precision assessment (Fleiss, 1971). Hence, the Kappa coefficient is calculated from the LUC error matrix as follows:

$$
\operatorname{Kappa}(\kappa)=\frac{\sum_{i}^{i=q} P i i-\sum_{i}^{i=q} P i_{+} * P+i}{1-\sum_{i}^{i=q} P i_{+} * P+i}
$$

where $P i i=N i j / N$ (i.e. proportion of the correctly counted LUC or ratio of diagonal value to the total number of observation); $P i_{+}=N i / N$ (i.e, proportion of the marginal row total); $P+i=$ 
$\mathrm{Mi} / \mathrm{N}$ (i.e. proportion of the marginal column total). Statistical analyses were carried out in R 3.3.2 and SPSS ver. 21 software packages while all mapping was done in ArcGIS 10.1.

\section{Results}

\subsection{Geomorphic settings}

Sedimentary rocks with calcium carbonate dominate the study area followed by sedimentary rocks without

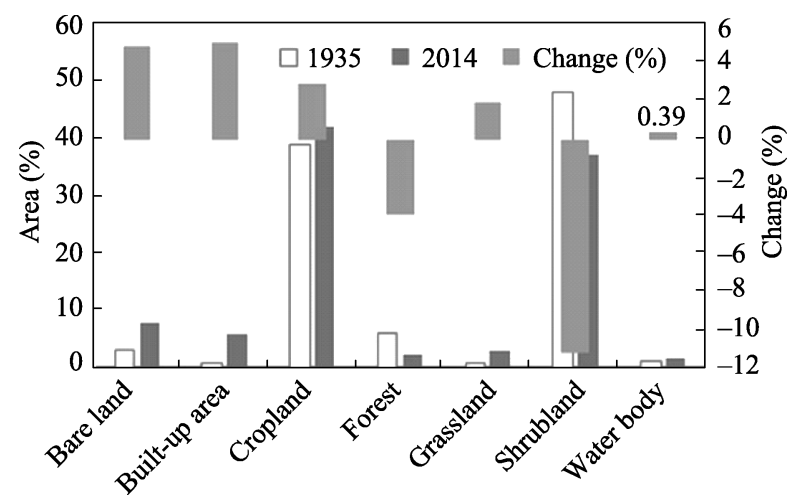

Figure 3 Areal percentage of different land use/cover types in the 1930s and $2014(n=34192)$ calcium carbonate such as sandstones (17\%), while volcanic rock covers a smaller area (10\%) (Supplementary Figure S2a). The soil type of southern and central Geba is categorized as suitable (34\%) and the northern and southwestern parts are moderately suitable (35\%) while eastern areas are dominantly non-suitable soils (31\%) (Supplementary Figure S2a). The distribution of the soil suitability classes is related to the geology and topography of the catchment (Tielens, 2012; IUSS, 2015).

\subsection{Change of LUC fraction from the 1930s-2014}

Despite the difficulty of stereo viewing due to high obliquity and small, overlapping area of vertical photos, the 1930s APs are found to be an important source of historical information. Field observation for the verification of the point counting method has resulted in a high overall accuracy (93\%) for the recent LUC, as shown in the error matrix (Table 2). The count of shrubland and cropland led to a high accuracy (i.e. a low omission error), 97\% and 93\% respectively, while the forest count resulted in a low accuracy. The error matrix shows that other land (summation of bare land, housing, waterbody, grassland) was identified with a high accuracy $(89 \%)$ or low errors. Moreover, the error matrix caused a very strong Kappa coefficient $(\kappa=0.89)$ (Table 2$)$. The accuracy assessment for the 1930 s LUC was not possible to do through a field visit but showed a high correspondence $(86 \%)$ to the result of the interview carried out on the old people concerning the history of land use in ancient times. The interviewed people with an average age of 69 years have explained the historical LUC of their area with some important landmarks, which they remember or which is based on what they heard from their parents. For example, the forests and shrubs in which they were cutting trees for different purposes such as to build their house and fence, for firewood and farming implements do not exist or are being degraded now.

The results of the quantitative analysis indicate that shrubland and cropland were the dominant LUC in both the 1930s and 2014. In the 1930s, the percentage of shrubland and cropland covers $48 \%$ and $39 \%$ respectively, but in 2014 the cropland outstretched to $42 \%$, while the shrubland contracted to $37 \%$ (Figure 3). All LUC categories (except shrubland and forests) have increased over the last 80 years (Figure 3).

The test of LUC fractions using Mann-Whitney U tests showed significant differences between the 1930s and 2014 for all categories except for cropland and forest. This test re- 
vealed that the fraction of shrubland decreased significantly in 2014 as compared to the 1930s while the bare land, grazing land, built-up area and water body had increased significantly in 2014 compared with the 1930s. The forest cover has dropped from about $6.3 \%$ to $2.3 \%$ during the last 80 years.

\subsection{Spatial distribution of land use/cover}

In the 1930s, shrubland and cropland were frequently observed (greater than $90 \%$ ) categories at sample locations while the other categories occurred in less than $45 \%$ of the total sample areas. In 2014, all LUC classes had been encountered in about $85 \%$ of the observation $(n=139)$, except forest and water body which occurred in $45 \%$ and $71 \%$, respectively (see Supplementary Figure S4). LUC types have undergone dynamic changes (increase or decrease) over a long time period (Figures 2-4). Nevertheless, there are cases where constant fractions and patterns of LUC were observed over this period. The chi-square test for the frequencies of spatial occurrence across the sample areas reveals significant changes in the location of occurrence of LUC except for forests (Supplementary Table S2).

Although cropland did not experience significant changes in fraction between two times, it showed however important spatial changes. In other words, some land that was under agriculture in the 1930s, was abandoned in 2014 and new agricultural lands were created by converting other LUC. The constant fraction of the cropland over a long period was retained at the expense of the other LUC mainly by encroaching and/or expanding into shrubland and forests, and abandonment of marginal, exhausted land, as well as the steepest slopes ban by administrative decision. This study also shows a significant decline in the spatial distribution of shrubland and the expansion of bare lands, grasslands and built-up areas (Supplementary Figure S4, Supplementary Table S2).

The change matrix (based on point counting) revealed a complex transformation of LUC over the last 80 years (Table 3). It should be noted that this transformation matrix is not free from errors due to the obliqueness of the APs and the non-georeferenced grid points on APs, which have resulted in a few meters' displacement of points on GE as compared to their location on AP. Nevertheless, the matrix showed that all LUC have replaced each other although the transformation intensity is variable (Table 3). The results indicate that about $67 \%$ and $54 \%$ of the cropland and shrubland respectively, remained spatially unchanged in 80 years, while only $5 \%$ of the forest was recorded at its location in the 1930s. A large portion of cropland has transformed into shrubland, built-up area, bare land and grazing land; shrubland transformed into cropland, bare land, built-up area and grazing land while forest mainly changed into shrubland to cropland in the order of importance.

\subsection{Explanatory factors affecting the land use/cover}

The results of the MARS model have revealed the importance of different factors for the occurrence probability of different LUC types in the 1930s and in 2014 (Table 4). The models show that all climatic environmental and socio-economic variables considered in this study have significantly affected one or more LUC types. However, the pressure of the socio-economic factors (i.e. the population density, distance to town) on LUC change have been increasing after the 1930s. For each model, several variables and terms (basis functions) were used to predict the LUC occurrences (Table 4 and Supplementary Table S3). The occurrence of more than one basis function for a single explanatory factor in a model depicts 

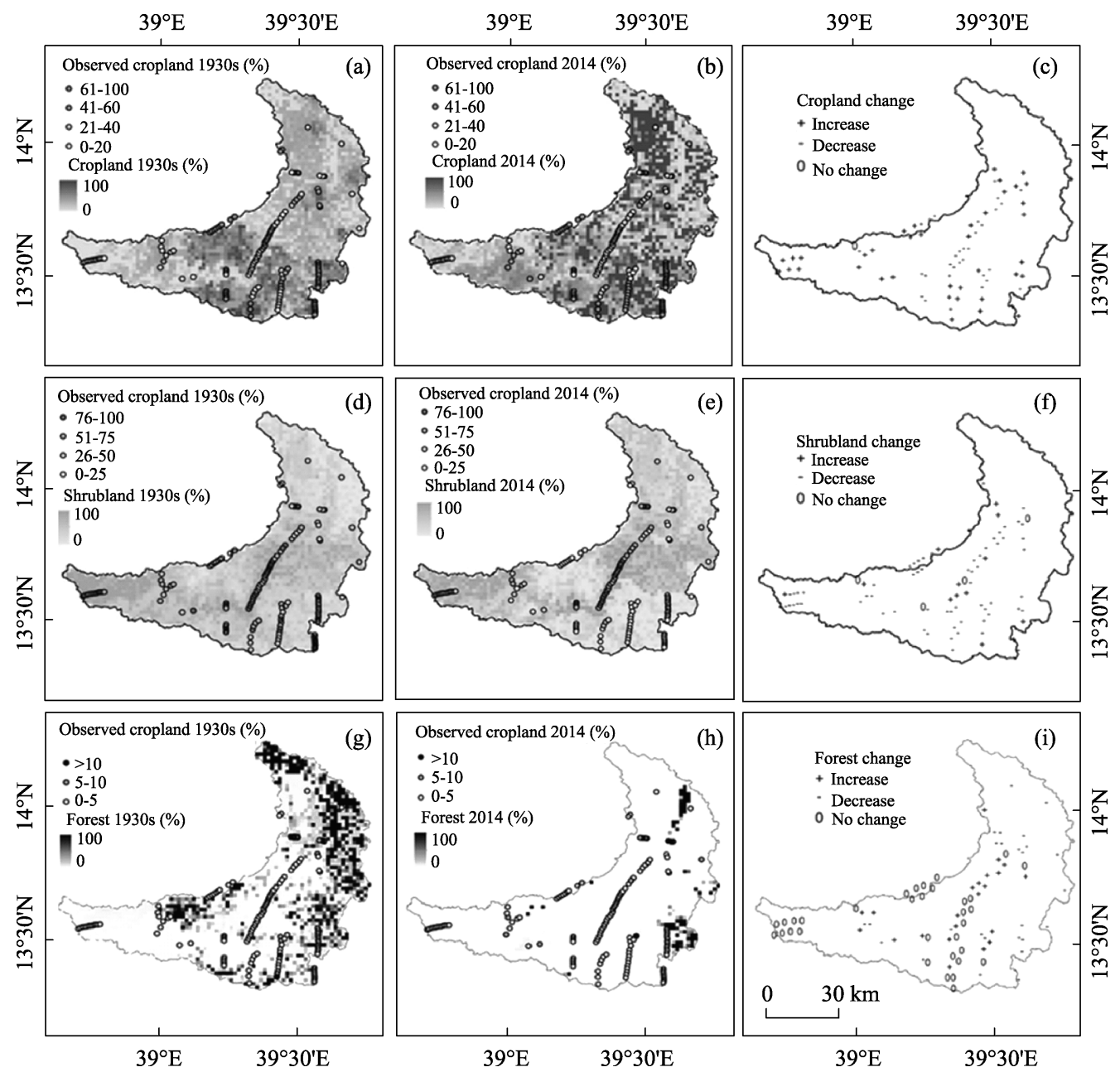

Figure 4 The spatial distribution and change of three dominant land use/cover of the study area: Cropland (a-c), shrubland $(\mathrm{d}-\mathrm{f})$ and forest $(\mathrm{g}-\mathrm{i})$. A positive $(+)$ and negative $(-)$ sign in these figures indicates the spatial expansion and shrinkage of LUC types, respectively. Graduated classifications illustrate the percent occurrence of land use type in the 1930s and 2014 that also reveal the degree of spatial changes within each location. Sd, Sf1, Sf2, Sh and Ss are supplementary data at Dergajen, Dessa forest 1, Dessa forest 2, Hadinet and Sinkata respectively.

Table 3 Land use/cover transformation matrix from the 1930 s to 2014 in Geba catchment

\begin{tabular}{lcccccccc}
\hline \multicolumn{1}{c}{$\begin{array}{c}\text { 1935/ } \\
2014\end{array}$} & Cropland & $\begin{array}{c}\text { Shrub } \\
\text { land }\end{array}$ & Forest & $\begin{array}{c}\text { Grazing } \\
\text { land }\end{array}$ & Built-up & $\begin{array}{c}\text { Bare } \\
\text { land }\end{array}$ & $\begin{array}{c}\text { Water } \\
\text { body }\end{array}$ & $\begin{array}{c}\text { Total } \\
\text { Cropland }\end{array}$ \\
$\begin{array}{l}\text { Shrub } \\
\text { land }\end{array}$ & 9047 & 2193 & 116 & 434 & 920 & 714 & 168 & 13592 \\
Forest & 4195 & 9151 & 351 & 460 & 680 & 1701 & 289 & 16827 \\
Grazingland & 514 & 861 & 84 & 36 & 123 & 80 & 17 & 1715 \\
Bare land & 125 & 95 & 12 & 18 & 85 & 21 & 6 & 362 \\
Built-up & 265 & 410 & 12 & 23 & 60 & 226 & 23 & 1019 \\
Water body & 79 & 29 & 4 & 7 & 117 & 10 & 1 & 247 \\
Total & 67 & 177 & 5 & 7 & 40 & 75 & 59 & 430 \\
\hline
\end{tabular}


Table 4 Relative importance of variables in the model using three criteria number of subset (the number of model subset that includes the variables), RSS (the scaled summed decrease of residual sum of squares overall subset) and Generalized Cross Validation (GCV). For the explanation on the variables see Table 1

\begin{tabular}{|c|c|c|c|c|c|c|c|c|}
\hline & \multicolumn{4}{|c|}{$1930 \mathrm{~s}$} & \multicolumn{4}{|c|}{2014} \\
\hline & Predictor & $\begin{array}{c}\text { Number of } \\
\text { subset }\end{array}$ & $\mathrm{GCV}$ & RSS & Predictor & $\begin{array}{c}\text { Number of } \\
\text { subset }\end{array}$ & GCV & RSS \\
\hline \multirow{6}{*}{$\begin{array}{l}\text { Crop- } \\
\text { land }\end{array}$} & SS & 7 & 100 & 100 & SS & 8 & 100 & 100 \\
\hline & DT30s & 6 & 75 & 77 & $\mathrm{Pd}$ & 7 & 66 & 69 \\
\hline & Slope & 6 & 75 & 77 & Slope & 6 & 55 & 59 \\
\hline & Alt & 2 & 17 & 26 & Alt & 5 & 30 & 39 \\
\hline & SMS & 1 & 12 & 18 & SMS & 2 & 4 & 18 \\
\hline & \multicolumn{2}{|c|}{$\mathrm{GCV} R^{2}=0.52$} & \multicolumn{2}{|c|}{$R^{2}=0.64$} & \multicolumn{2}{|c|}{$\mathrm{GCV} R^{2}=0.63$} & \multicolumn{2}{|c|}{$R^{2}=0.73$} \\
\hline \multirow{5}{*}{$\begin{array}{c}\text { Shrub- } \\
\text { land }\end{array}$} & Alt & 3 & 100 & 100 & SS & 5 & 100 & 100 \\
\hline & Slope & 2 & 54 & 58 & Slope & 4 & 51 & 55 \\
\hline & SNS & 1 & 28 & 33 & Alt & 3 & 32 & 38 \\
\hline & & & & & SMS & 1 & 13 & 18 \\
\hline & \multicolumn{2}{|c|}{$\mathrm{GCV} R^{2}=0.38$} & \multicolumn{2}{|c|}{$R^{2}=0.44$} & \multicolumn{2}{|c|}{$\mathrm{GCV} R^{2}=0.58$} & \multicolumn{2}{|c|}{$R^{2}=0.64$} \\
\hline \multirow{6}{*}{ Forest } & Slope & 6 & 100 & 100 & Alt & 6 & 100 & 100 \\
\hline & Alt & 6 & 100 & 100 & LSC & 6 & 100 & 100 \\
\hline & SNS & 6 & 100 & 100 & $\mathrm{Pd}$ & 6 & 100 & 100 \\
\hline & LSC & 4 & 36 & 49 & SS & 6 & 96 & 97 \\
\hline & LSNC & 2 & 25 & 34 & & & & \\
\hline & \multicolumn{2}{|c|}{$\mathrm{GCV} R^{2}=0.40$} & \multicolumn{2}{|c|}{$R^{2}=0.52$} & \multicolumn{2}{|c|}{$\mathrm{GCV} R^{2}=0.31$} & \multicolumn{2}{|c|}{$R^{2}=0.47$} \\
\hline
\end{tabular}

the nonlinear relations between the explanatory factors and LUC categories. The regression models have also illustrated the significant interaction of the explanatory factors on the distribution of LUC (Supplementary Table S3). The results also demonstrated different thresholds for different explanatory variables in the 1930s and 2014.

Among all the considerable variables, the slope gradient, elevation, soil suitability for cropping and proximity to town were significantly influencing the cropland fraction in the 1930 s explaining $64 \%$ of the probability of its occurrences. The soil type which was the main suitable soil for cultivation was the most important factor for the occurrence of a larger fraction of cropland in the 1930s followed by the slope gradient and the distance from town. The result shows that in moderately sloping to flat areas (i.e. a slope gradient of less than $16 \%$ ), the fraction of cropland was positively affected while the fraction was decreasing when the proximity of the area to town decreased except in suitable soil areas (Supplementary Table S3). Similarly, in 2014, the soil type and slope gradient remained the dominant factors for determining the distribution of cropland in which suitable soil and slope gradients of less than $16 \%$ were increasing the fraction of cropland. However, the effects of suitable soils and slope gradients were reversed when combined with the population density. The MARS also showed a larger cropland fraction in mid to high elevation areas except at steep slope gradients during the 1930s and 2014 (Supplementary Table S3). From the MARS model, it is also apparent that the distribution of shrubland was highly dependent on the slope gradient but in reverse direction to the cropland distribution. In flat areas, the fraction of shrubland was negatively affected while in sloping and steep slope areas the coverage had increased in the 1930s and 2014. Moreover, soil types and elevation were also other dominant explanatory factors for the distribution of shrubland. The result showed that suitable 
soil for cultivation favoured the occurrence of shrubs while suitable and moderately suitable soils affected the distribution of shrubland negatively. Moreover, the results revealed that when elevation increases over circa1800 $\mathrm{m}$ the fraction of shrubland had decreased both in past and present times (Supplementary Table S3).

During the 1930s and 2014, elevation, lithologies, soil suitability and slope gradients showed an important relation to the presence of forests although their explanatory power was weak $\left(R^{2}=0.52\right.$ in the $1930 \mathrm{~s}$ and $R^{2}=0.47$ in 2014) (Table 4). In both the 1930s and 2014, the elevation was the most important factor for the occurrences of forest in which a larger fraction of forest exists in areas with an elevation of over $1900 \mathrm{~m}$. The interaction of elevation and lithology, soil suitability and population density resulted in different fractions of forest. The result also depicted that it was unlikely to find forest in areas with suitable soil for cultivation, while the increase of population density affected the forest occurrence positively, particularly in 2014.

The multivariate regression models developed for different LUCs in the 1930s and 2014 were used to calculate fraction maps of three major LUC types (i.e. cropland, shrubland and forest) at least five spatial raster layers, which represent the explanatory factors, were prepared to create the fractional maps of cropland, shrubland and forest in the 1930s and 2014. Hence, these fractional maps indicated the spatio-temporal distributions and the changes of LUC. The mapping of LUC of the Geba catchment (Figure 4) was done by $1.5 \mathrm{~km} \times 1.5 \mathrm{~km}$ grid of the important explanatory factors in each model. As the values of every pixel are not absolute, percentages of different LUC types, separate maps were produced for the cropland, shrubland and forest. Colour gradients of each LUC have been used to compare the percentages of areal distribution and changes of LUC in the study area over the last 80 years. In these maps high gradients (larger percentages) of a different LUC did not occur on the same location, although mixed LUCs having a smaller percentage on a particular location are observed (Figure 4). Given the several limiting factors for the inaccurate mapping of LUC, the validation of the maps of 2014 using 233 random points on GE showed a high accuracy for cropland $(86 \%)$ and shrubland $(84 \%)$ and a lower one for the forest map $(60 \%)$ and other land covers $(71 \%)$. Overall, the confusion matrix showed a higher overall accuracy for the fractional map (83\%) and a very strong Kappa coefficient (72\%) (Table 2).

\section{Discussion}

\subsection{Point counting method, APs and GE images}

The high overall accuracy (93\%) and a very strong Kappa coefficient agreement (89\%) of LUC counting as shown in the error matrix (Table 2), validated that counting LUC on Google Earth was done accurately. A good visualization and a high resolution nature of GE motivates, beside its potential for validation, its direct application in the environmental inventories includes LUC studies (Frankl et al., 2013b; Fritz et al., 2009; Hu et al., 2013). The medium scale and zooming technique make the photographs comparable to the Google Earth image resolution and viewing, which suggests the appropriateness of the comparison of results from the two sources. Frankl et al. (2013b) have used a combination of historical aerial photographs and GE images so as to analyze the temporal change of a gully network in Northern Ethiopia. Further, we are aware of only one study that used aerial photographs 
produced between 1936 and 1941 at a scale of 1:64,000 for a land use cover change study in Texas and New Mexico, United States (Scanlon et al., 2007).

\subsection{Land use/cover fraction}

Cropland showed a slight increment over the long time period. Despite the rapid rise of the human population (Nyssen et al., 2009), whose livelihood largely depends on agriculture (Deressa et al., 2008), the area of cultivated land remained almost constant during a long period of time. This indicates that suitable land for agriculture had been entirely occupied for many years, probably centuries, in Northern Ethiopia. Similar results have been reported locally in the catchment (that cultivated lands nearly did not expand over tens of years) (Alemayehu et al., 2009; Meire et al., 2013; Teka et al., 2013). Mitiku et al. (2006) documented that limits to lands (suitable for agriculture) are reached in Northern Ethiopia and that food demands for the increasing population could be met through an intensified use of the existing cropland. On the contrary, a significant expansion of cropland occurred in other parts of Ethiopia (e.g. Rembold et al., 2000; Zeleke and Hurni, 2001; Tsegaye et al., 2010), Africa and worldwide (Lambin et al., 2003; MEA, 2005) during the second half of the 20th century. Dynamic changes (expansion or contraction, rapid or slow) of cropland were reported in the southwest of Ethiopia despite a rapid population growth in the region in the last 50 years (Reid et al., 2000). On the other hand, the most dominant land cover in the 1930s, namely shrubland, has significantly decreased in fraction over the last 80 years. The decline might not only be visible in the land's percentage under shrub cover but the quality of the shrubland might also have deteriorated compared to history, although it had not been quantified. Field visits demonstrated that in 2014 , the shrubs had a low plant density and an open canopy cover. The forest showed a declining trend from its already low percentage in the 1930 s (from $6.3 \%$ to $2.3 \%$ ). This small fraction of forest cover in the 1930 s indicates that the forest resources had been cleared, even before the 1930s. Despite the strong claims on a dense forest cover in the 1930s in Ethiopia (including our study region), there is no reliable record of forest cover and no precise date and rate of deforestation (Pankhurst, 1995; Woien, 1995). Previous studies in or close to our study area have reported that the forest and shrubland illustrated an increment during the last three to five decades (Alemayehu et al., 2009; Teka et al., 2015; Meire et al., 2013; de Muelenaere et al., 2014; Teka et al., 2013). However, our results may not be contradictory to such findings as their study period only extended to 1965 and covered small parts of the study area. The study carried out by Nyssen et al. (2015) in Northern Ethiopia concerning environmental conditions over the last 145 years indicates the highly variable land degradation. We thought that the woody vegetation cover peak at the end of the 1930s, strongly declined until large-scale soil and water conservation activities started in the 1990s. Hence, our results are in line with those of Nyssen et al. (2015): as compared to the 1930s, the land is still more degraded nowadays in Northern Ethiopia.

Despite extensive forest rehabilitation practices in Northern Ethiopia, there was an exceptionally ongoing deforestation on the remnant natural forest in the region (Munro et al., 2008). Recent deforestation has been detected in the Mt. Lib Amba and Simien Mountains, Northern Ethiopia (Jacob et al., 2015, 2017). Our results also clarify an increase in bare land, grassland, built-up area and water body, which is in agreement with earlier findings (Alemayehu et al., 2009; Meire et al., 2013; Teka et al., 2013), particularly before the start of the SWC practices. The overall decline of vegetation in the last 80 years is also in line 
with the existence of larger areas where the SWC (including exclosure) has not been fully implemented, for example in the lower parts of the study area, which are relatively remote.

\subsection{Spatial change of land use/cover}

Considerable spatial changes of LUC have taken place over the last 80 years. In the 1930s, less heterogeneity of land use in aerial photography (scenes) was observed as compared to the data of 2014. In other words, LUCs were less fragmented in the 1930s. By 2014, LUC classes had encroached upon the land that was under different use/cover during the 1930s. Hence, it is not uncommon to observe a mosaic LUC, such as cropland that encroached shrubland, a tree plantation (mainly Eucalyptus) in cropland as patches or in a linear form (Meire et al., 2013), settlement and water body in cropland and so on. However, this study has a limitation of showing the spatio-temporal dynamism of LUC change over the last 80 years in the Geba catchment, due to a lack of intermediate time period data on LUC.

Although cropland did not show a significant change in fraction over a long time (section 4.2), an important spatial change was noted that about $33 \%$ of the cropland was transformed to a different LUC, mainly to shrubland, built-up area and bare lands (Table 3). It is obvious that cropland, which lost its productivity due to an exhaustive cultivation, can no longer be used as cropland but is converted to bare land, degraded grazing land or shrubland, unless it is reclaimed. On the other hand, lands that were under shrub, forest and grass in the 1930s was converted to cropland in 2014, probably to search fertile soils. This result is consistent with previous studies (e.g. Zeleke and Hurni, 2001; Alemayehu et al., 2009). There are also some areas where bare lands were converted to cropland which shows the critical shortage of suitable lands for cropping leading an agricultural expansion into marginal lands. Shrubland was also affected by an increase of grazing land, which can be explained by the rise in livestock production associated with the population growth. The transformation of forest into shrubland and cropland in 2014 shows that deforestation had continued over the last 80 years. The conversion of bare lands to forest and shrubland can be linked to the plantation forest and the implementation of exclosures over the last few decades. Considerable fraction of built-up area were recorded in 2014 on the locations previously (1930s) covered by cropland, shrubland and forest which can be linked to a rapid population increase. Other studies also indicate that built-up areas (mainly urban areas) increased at the expense of cropland in Ethiopia during the last few decades (Haregeweyn et al., 2012; Miheretu and Yimer, 2017).

\subsection{Explanatory factors of land use/cover distribution and change}

Overall, over the last 80 years, the study area had been hit by two major droughts and several famines. The common explanation for LUC change in earlier research carried out in the north or in other parts of Ethiopia, comprises the socio-economic forces, policies and institutions (Alemayehu et al., 2009; Teka et al., 2015; Meire et al., 2013; de Muelenaere et al., 2014; Tadesse et al., 2014; Teka et al., 2013). Physical elements are rarely correlated to LUC changes (Reid et al., 2000; Tadesse et al., 2014), though they trigger significant changes particularly when the land is under stress (Lambin et al., 2001). The present study demonstrated that consideration of topography, soil type and lithology as potential explanatory factors of LUC occurrence, provided a moderate to high model fitting and the validation of results, particularly for cropland and shrubland.

Despite the shortage of suitable cultivation lands in the study area for a long time, steep 
slope areas remained unsuitable for agriculture. Other reports also indicate that arable lands are frequently observed on level to gentle slope lands (plains, foot slopes and valley floors) (Meire et al., 2013; Teka et al., 2013). But currently, cropland sometimes appears on steep slopes where soil and water conservation (SWC) measures like stone bunds or trenches are executed so as to counter soil erosion. This is in line with a previous study on long-term land use change in the same region (Meire et al., 2013). The current inverse correlation between the population density and the cropland fraction describes the conversion of cropland to built-up (such as housing, roads) areas following a population increase. Ramankutty et al. (2002) explained that the rapid population increase and urbanization resulted in less cropland area per capita. Jacob et al. (2015) have analyzed an increase of the tree line elevation in mountainous areas due to anthropogenic pressure. On the other hand, steep slope lands appear to be reserved for shrub use in the study area, (which is) explained by the extensive conservation measures that had been carried out in degraded areas of the Tigray region during the last two to three decades. Exclosures, as part of SWC, were mostly applied on very steep and degraded slopes, which suffer from a severe soil erosion. Various reports illustrated that sloping and steep areas are often employed for afforestation in Northern Ethiopia (Descheemaeker et al., 2006b). Forests that grew in suitable soils for cropping in the 1930s, had been deforested in 2014. Hence, in 2014, remnants of forests were available in areas where the soils are moderately suitable and non-suitable for cropping, sandstone and sloping, which appear to the fact that afforestation is promoted in less fertile soils. Currently, the forest density has augmented nearby towns which can be linked to the increased awareness of tree growing and management in the Tigray region (de Muelenaere et al., 2014). Clusters of forests planted along farmland boundaries and in villages are commonly encountered in the region (Meire et al., 2013).

The creation of fractional maps on different LUCs in the Geba catchment, which use model developed for each class with a set of explanatory elements, resulted in an approximately similar pattern with the observed fractions (Figure 4). It is important to possess proportional samples of AP/GE (in different explanatory factors) (Supplementary Figure S1) for the prediction of land use/ cover distribution in the entire catchment. The verification of these maps using Google Earth images (2014) showed the model validity in order to predict the occurrence of LUC, particularly for 2014. Overall, $84 \%$ of the LUC was correctly allocated on the fractional map of LUC. Cropland and shrubland were more or less predicted accurately, while large errors had been noticed in the forest prediction. This poor forecast accuracy can be related to the small fraction of forest in each scene which less likely dominates the scene. Moreover, the very strong Kappa coefficient agreement $(k=72)$ confirms the validity of the created fractional maps. In general, this result suggests that the models we developed for the Geba catchment are reliable to foretell the fraction of LUC change, while using the important explanatory factors selected in each model (Table 4 and Supplementary Table S3).

\section{Conclusions}

This study demonstrated the usefulness of the analysis of the 1930s APs and GE images for the study of land/cover distribution and changes. The results have demonstrated significant modifications in the fraction and spatial shifts of LUC during the last 80 years. Despite in- 
significant changes in the fraction of cropland area, $39 \%$ in the 1930 s to $42 \%$ in 2014 , it partially shifted its location at the expense of other LUC. The transformation matrix illustrates that $33 \%$ of the cropland was given away to different LUC types, mainly to shrubland, bare land, and grassland probably due to its decreasing productivity and change to built-up areas, which can be explained by a rapid population growth. Shrubland is the most affected LUC over this long time period, as it significantly shrank from $48 \%$ in the 1930 s to $37 \%$ in 2014 , associated with a shift of cropland and an expansion of the built-up area and grazing land. Forest cover has dropping continuously in the last 80 years, from about $6.3 \%$ through an absolute minimum in the 1970 s- 1980 s to less than $2.3 \%$ in 2014 . The increased frequency of occurrence of different LUC types in observation areas (scenes) shows a more mixed or fragmented LUC system in 2014 compared to the 1930 s.

The effects of different forces (environmental and socio-economic variables) on LUC distribution was indicated by non-linear regression analysis. This study also indicates that explanatory factors influence LUC types at different thresholds. Cropland was generally recorded in flat to sloping areas $(<16 \%)$, while shrubland and forest were often seen on slopes above $5 \%$, although the thresholds change when other important factors exist. The latter (such as elevation, soil suitability, lithology and socio-economic factors) were also very important for influencing the distribution of cropland, shrubland and forest. The comparison of the fractional maps with the observed fraction reveals similar patterns in their distribution. The validation of this fractional map on Google Earth demonstrated a high overall accuracy $(83 \%)$ and a strong Kappa coefficient (72\%), which confirm the usefulness of the databases (GE and explanatory factors) and the MARS model in order to create an accurate LUC fractional map of LUC.

Overall, this study provided useful information regarding the condition of LUC in the Geba catchment in the 1930s and 2014, demonstrating larger areal fractions of shrubland and forest and an approximately constant cropland area in the1930s as compared to 2014. This suggests that more efforts of land management (SWC and exclosure) practices need to be implemented particularly in remote areas. Moreover, further investigation on the historical LUC of the study area could prove the database on the environmental condition in the past so as to evaluate the ongoing SWC interventions or to design new land management strategies.

\section{Acknowledgements}

This research was carried out thanks to a scholarship of the Special Research Fund (BOF) obtained from Ghent University, Belgium. Costs during the field works were partially covered by the RIP-MU (VLIR, Belgium) project. The Mekelle University is acknowledged for its facilitations and logistic arrangements for this research. Samuele Tesfaye contributed largely by sharing data and providing technical GIS assistance. Thanks to Sabine Cnudde for proofreading of this manuscript. Finally, we are grateful to Mr. Kahsu Kiros for the many rides over bad roads to access the field areas.

\section{References}

Aerts R, Van Overtveld K, November E et al., 2016. Conservation of the Ethiopian church forests: Threats, opportunities and implications for their management. Sci. Total Environ., 551: 404-414. doi: 10.1016/ j.scitotenv.2016.02.034. 
Alemayehu F, Taha N, Nyssen J et al., 2009. The impacts of watershed management on land use and land cover dynamics in Eastern Tigray (Ethiopia). Resour. Conserv. Recy., 53(4): 192-198. doi: 10.1016/j.resconrec.2008. 11.007.

Amanuel Z, 2009. Assessment of spatial and temporal variability of river discharge, sediment yield and sediment-fixed nutrient export in Geba River catchment, northern Ethiopia [D]. K.U. Leuven, Belgium.

Annys S, Demissie B, Amanuel Zenebe et al., 2017. Land cover changes as impacted by spatio-temporal rainfall variability along the Ethiopian Rift Valley escarpment. Reg. Environ. Change, 17(2): 451-463. doi: 10.1007/ s10113-016-1031-2.

Araya A, Keesstra SD, Stroosnijder L, 2010. A new agro-climatic classification for crop suitability zoning in northern semi-arid Ethiopia. Agric. For. Meteorol., 150: 1057-1064. doi: 10.1016/j.agrformet.2010.04.003.

Asmamaw L, Mohammed A, Lulseged T, 2011. LUC dynamics and their effects in the Gerado catchment, northeastern Ethiopia. Int. J. Environ. Stud., 68(6): 883-900. doi: 10.1080/00207233.2011.637701.

Bard K A, Coltorti M, DiBlasi M C et al., 2000. The environmental history of Tigray (Northern Ethiopia) in the Middle and Late Holocene: A preliminary outline. Afr. Archaeol. Rev., 17(2): 65-86. doi: 10.1023/ A:1006630609041.

Bastin L, Buchanan G, Beresford A et al., 2013. Open resource mapping and services for web-based land-cover validation. Ecol. Inform., 14: 9-16. doi: 10.1016/j.ecoinf.2012.11.013.

Bellhouse D, 1981. Area estimation by point-counting techniques. Biometrics, 37(2): 303-312. doi: 10.2307/ 2530419.

Biadgilgn Demissie, Frankl A, Mitiku Haile et al., 2015. Biophysical controlling factors in upper catchments and braided rivers in drylands. Land Degradation and Development, 26: 748-758. doi: 10.100/1de.2357.

CIESIN (Center for International Earth Science Information Network) - Columbia University, 2016. Gridded Population of the World, Version 4 (GPWv4): Population Density Adjusted to Match 2015 Revision UN WPP Country Totals. Palisades, NY: NASA Socioeconomic Data and Applications Center (SEDAC). http://dx.doi.org/10.7927/H4HX19NJ. Accessed 20 March 2016.

Congalton R, Oderwald R, Mead R, 1983. Assessing landsat classification accuracy using discrete multivariate analysis statistical techniques. Photogrammetric Engineering and Remote Sensing, 49(12): 1671-1678.

CSA, 2008. Summary and Statistics Report of the 2007 Population and Housing Census. Federal Democratic Republic of Ethiopia Population Census Commission. December 2008, Addis Ababa, Ethiopia, pp113.

Daniels R B, Gamble E E, Bartelli L J et al., 1968. Application of the point count method to problems of soil microbiology. Soil Science, 106(2): 149-152.

de Muelenaere S, Frankl A, Haile M et al., 2014. Historical landscape photographs for calibration of Landsat land use/cover in the Northern Ethiopian Highlands. Land Degrad. Dev., 25(4): 319-335. doi: 10.1002/1dr.2142.

Deressa T, Hassan R M, Alemu T et al., 2008. Analyzing the determinants of farmers' choice of adaptation methods and perceptions of climate change in the Nile Basin of Ethiopia. IFPRI Discussion Paper 00798, pp36.

Descheemaeker K, Nyssen J, Poesen J et al., 2006a. Runoff on slopes with restoring vegetation: A case study from the Tigray highlands, Ethiopia. J. Hydrol., 331(1): 219-241. doi: 10.1016/j.jhydrol.2006.05.015.

Descheemaeker K, Nyssen J, Rossi J et al., 2006b. Sediment deposition and pedogenesis in exclosures in the Tigray Highlands, Ethiopia. Geoderma, 132(3): 291-314. doi: 10.1016/j.geoderma.2005.04.027.

FAO, 2010. Global Forest Resources Assessment: Main report. Foresty paper 163, FAO. Rome, Italy.

FAO, 2011. Food and Agriculture Organization Ethiopia Country Programming Framework: 2012-2015. Office of the FAO Representative in Ethiopia to AU and ECA, Addis Ababa.

Fleiss J L, 1971. Measuring nominal scale agreement among many raters. Psychological Bulletin, 76: $378-382$.

Frankl A, Nyssen J De Dapper M et al., 2011. Linking long-term gully and river channel dynamics to environmental change using repeat photography (Northern Ethiopia). Geomorphology, 129(3): 238-251. doi: 10.1016/j.geomorph.2011.02.018.

Frankl A, Poesen J, Haile M et al., 2013a. Quantifying long-term changes in gully networks and volumes in dryland environments: The case of Northern Ethiopia. Geomorphology, 201: 254-263. doi: 10.1016/ j.geomorph.2013.06.025.

Frank1, A, Zwertvaegher A, Poesen J et al., 2013b. Transferring Google Earth observations to GIS-software: Example from gully erosion study. Int. J. Digital Earth, 6(2): 196-201. doi: 10.1080/17538947.2012.744777.

Frankl A, Seghers V, Stal C et al., 2015. Using image-based modelling (SfM-MVS) to produce a 1935 ortho-mosaic of the Ethiopian Highlands. Int. J. Digital Earth, 8(5): 421-430. doi: 10.1080/17538947. 
2014.942715.

Friedman J H, 1991. Multivariate adaptive regression splines. The Annals of Statistics, 19(1): 1-67.

Friedman J H, Silverman B W, 1989. Flexible parsimonious smoothing and additive modeling. Technometrics, 31(1): 3-21

Fritz S, McCallum I, Schill C et al., 2009. Geo-Wiki. Org: The use of crowdsourcing to improve global land cover. Remote Sensing, 1(3): 345-354. doi: 10.3390/rs1030345.

Gebresamuel G, Singh B R, Dick O, 2010. Land-use changes and their impacts on soil degradation and surface runoff of two catchments of Northern Ethiopia. Acta Agr. Scand. BSP, 60(3): 211-226. doi: 10.1080/ 09064710902821741.

Gebru T, Eshetu Z, Huang Y et al., 2009. Holocene palaeovegetation of the Tigray Plateau in northern Ethiopia from charcoal and stable organic carbon isotopic analyses of gully sediments. Palaeogeogr. Palaeoclimatol. Palaeoecol., 282(1): 67-80. doi: 10.1016/j.palaeo.2009.08.011.

Goldewijk K K, 2001. Estimating global land use change over the 1930s 300 years: The HYDE database. Glob. Biogeochem. Cycles, 15(2): 417-433. doi: 10.1029/1999GB001232.

Goldewijk K K, Ramankutty N, 2004. Land cover change over the last three centuries due to human activities: The availability of new global data sets. GeoJournal, 61(4): 335-344. doi: 10.1007/s10708-004-5050-z.

Hadush G, 2012. Modeling of Hydrological Process in the Geba Riv er Basin in the northern Ethiopia [D]. Brussels, Belgium: Vrije Universiteit.

Haregeweyn N, Fikadu G, Tsunekawa A et al., 2012. The dynamics of urban expansion and its impacts on land use/land cover change and small-scale farmers living near the urban fringe: A case study of Bahir Dar, Ethiopia. Landscape and Urban Planning, 106(2): 149-157.

Hoffer R, 1975. Natural resource mapping in mountainous terrain by computer analysis of ERTS-1 satellite data. Purdue University. LARS Research Bulletin, 919: 124 pp.

HTS, 1976. Tigrai Rural Development Study, Annex 1. Land and Vegetation Resources. Hunting Technical Services Ltd: Hemel Hempstead.

$\mathrm{Hu} \mathrm{Q}, \mathrm{Wu}$ W, Xia T et al., 2013. Exploring the use of Google Earth imagery and object-based methods in land use/cover mapping. Remote Sensing, 5(11): 6026-6042. doi: 10.3390/rs5116026.

Hurni H, Tato K, Zeleke G, 2005. The implications of changes in population, land use, and land management for surface runoff in the upper Nile basin area of Ethiopia. Mountain Research and Development, 25: 147-154.

Hurni H, Wiesmann U, 2010. Global change and sustainable development: A synthesis of regional experiences from research partnerships. University of Bern. Switzerland. Perspectives of the Swiss National Centre of Competence in Research (NCCR) North-South, University of Bern,Vol. 5. Bern, Switzerland: Geographica Bernensia, 578 pp.

IGM. Instituto Geografico Militare, Ente Cartografico dello Stato, 2012. www.igmi.org. Accessed 10 January 2016.

Jacob M, Frankl A, Beeckman H et al., 2015. North Ethiopian Afro-alpine tree line dynamics and forest cover change since the early 20th century. Land Degrad. Dev., 26: 654-664. doi: 10.1002/ldr.2320.

Jacob M, Frankl A, Hurni H et al., 2017. Land cover dynamics in the Simien Mountains (Ethiopia), half a century after establishment of the National Park. Reg. Environ. Change, 17: 777-787. doi: 10.1007/s10113-0161070-8.

Kidane G, Dejene A, Malo M, 2010. Agricultural based Livelihood Systems in Drylands in the Context of Climate Change: Inventory of Adaptation Practices and Technologies of Ethiopia. Environment and Natural Resource Working Paper 38, FAO, Rome, 57pp.

Lambin E F, Geist H J, Lepers E, 2003. Dynamics of land-use and land-cover change in tropical regions. Annu. Rev. Environ. Resour., 28(1): 205-241. doi: 10.1146/annurev.energy.28.050302.105459.

Lambin E F, Turner B L, Geist H J et al., 2001. The causes of land-use and land-cover change: Moving beyond the myths. Glob. Environ. Chang. 11(4): 261-269. doi: 10.1016/S0959-3780(01)00007-3.

Lanckriet S, Derudder B, Naudts J et al., 2015. A political ecology perspective of land degradation in the north Ethiopian Highlands. Land Degrad. Dev., 26: 521-530. doi: 10.1002/ldr.2278.

Lepers E, Lambin E F, Janetos A C et al., 2005. A synthesis of information on rapid land-cover change for the period 1981-2000. BioScience, 55(2): 115-124. doi: 10.1641/0006-3568.

Loelkes G L, Howard G E, Schwertz E L et al., 1983. Land use/land cover and environmental photointerpretatlon keys. U.S. Geological Survey Bulletin, 1600.

Maitima J M, Mugatha S M, Reid R S et al., 2009. The linkages between land use change, land degradation and 
biodiversity across East Africa. LUCID Working Paper, No.42. Nairobi (Kenya): ILRI. http://hdl.handle.net/ 10568/1934.

Meire E, Frankl A, De Wulf A et al., 2013. Land use/cover dynamics in Africa since the nineteenth century: warped terrestrial photographs of North Ethiopia. Reg. Environ. Chang., 13(3): 717-737. doi: 10.1007/s10113012-0347-9.

Mengistu D A, Waktola D K, Woldetsadik M, 2012. Detection and analysis of land-use and land-cover changes in the Midwest escarpment of the Ethiopian Rift Valley. J. Land Use Sci., 7(3): 239-260. doi: 10.1080/1747423X. 2011.562556 .

MEA, 2005. Ecosystem and Human Well-being: Synthesis. Millennium Ecosystem Assessment, 2005. Washington DC: Island Press.

Miheretu B A, Yimer A A, 2018. Land use/land cover changes and their environmental implications in the Gelana sub-watershed of Northern Highlands of Ethiopia. Environmental Systems Research, 6(1): 7.

Mitiku H, Herweg K, Stillhardt B, 2006. Sustainable land management: A new approach to soil and water conservation in Ethiopia. Mekelle University, Mekelle, Ethiopia, University of Berne, Berne, Switzerland.

Munro R N, Deckers J, Haile M et al., 2008. Soil landscapes, land cover change and erosion features of the Central Plateau region of Tigrai, Ethiopia: Photo-monitoring with an interval of 30 years. Catena, 75(1): 55-64. doi: 10.1016/j.catena.2008.04.009.

Nyssen J, Frankl A, Mitiku Haile Hurni H et al., 2015. Environmental conditions and human drivers for changes to north Ethiopian mountain landscapes over 145 years. Sci. Total Environ., 485/486: 164-179. doi: 10.1016/j.scitotenv.2014.03.052.

Nyssen J, Haile M, Naudts J et al., 2009. Desertification? Northern Ethiopia re-photographed after 140 years. Sci. Total Environ., 407(8): 2749-2755. doi: 10.1016/j.scitotenv.2008.12.016.

Nyssen J, Naudts J, De Geyndt K et al., 2008a. Soils and land use in the Tigray highlands (Northern Ethiopia). Land Degrad. Dev., 19(3): 257-274. doi: 10.1002/ldr.840.

Nyssen J, Petrie G, Mohamed S et al., 2016. Recovery of the aerial photographs of Ethiopia in the 1930s. J. Cult. Herit., 17: 170-178. doi: 10.1016/j.culher.2015.07.010.

Nyssen J, Poesen J, Descheemaeker K et al., 2008b. Effects of region-wide soil and water conservation in semi-arid areas: The case of northern Ethiopia. Z. Geomorphol., 52(3): 291-315. doi: 10.1127/ 0372-8854/ 2008/0052-0291.

Nyssen J, Vandenreyken H, Poesen J et al., 2005. Rainfall erosivity and variability in the Northern Ethiopian Highlands. J. Hydrol., 311(1): 172-187. doi: 10.1016/j.jhydrol.2004.12.016.

Pankhurst R, 1995. The history of deforestation and afforestation in Ethiopia prior to World War I. Northeast African Studies, 2(1): 119-133.

Quiros E, Felicísimo A M, Cuartero A, 2009. Testing multivariate adaptive regression splines (MARS) as a method of land cover classification of TERRA-ASTER satellite images. Sensors, 9(11): 9011-9028. doi: $10.3390 / \mathrm{s} 91109011$.

Ramankutty N, Foley J A, 1999. Estimating historical changes in global land cover: Croplands from 1700 to 1992. Glob. Biogeochem. Cycles., 13(4): 997-1027. doi: 10.1029/1999GB900046.

Ramankutty N, Foley J A, Olejniczak N J, 2002. People on the land: Changes in global population and croplands during the 20th century. Ambio, 31(3): 251-257.

Reid R S, Kruska R L, Muthui N et al., 2000. Land-use and land-cover dynamics in response to changes in climatic, biological and socio-political forces: The case of southwestern Ethiopia. Landsc. Ecol., 15(4): 339-355. doi: 10.1023/A:1008177712995.

Rembold F, Carnicelli S, Nori M et al., 2000. Use of aerial photographs, Landsat TM imagery and multidisciplinary field survey for land-cover change analysis in the lakes region (Ethiopia). International Journal of Applied Earth Observation and Geoinformation, 2(3/4): 181-189.

Romanov P, Tarpley D, Gutman G et al., 2003. Mapping and monitoring of the snow cover fraction over North America. J. Geophys. Res., 108(D16): 8619. doi: 10.1029/2002JD003142.

Saebo H V, 1983. Land Use and Environmental statistics obtained by point sampling. Central Bureau of Statistics of Norway. Artikler 144: 35pp.

Scanlon B R, Reedy R C, Tachovsky J A, 2007. Semiarid unsaturated zone chloride profiles: Archives of past land use change impacts on water resources in the southern High Plains, United States. Water Resour. Res., 43(W06423): 1-13. doi: 10.1029/2006WR005769.

Shockey W R, 1969. Point sampling of land use in the Washita Basin, United States Department of Agriculture, 
Agricultural research service. Archived Documents, 41-149.

Stehman S V, 1996. Estimating the Kappa Coefficient and its variance under stratified random sampling. Photogrammetric Engineering \& Remote Sensing, 62(4): 401-402.

Tadesse G, Zavaleta E, Shennan C et al., 2014. Policy and demographic factors shape deforestation patterns and socio-ecological processes in southwest Ethiopian coffee agroecosystems. Applied Geography, 54: 149-159. doi: 10.1016/j.apgeog.2014.08.001.

Taye G, Poesen J, Wesemael B V et al., 2013. Effects of land use, slope gradient, and soil and water conservation structures on runoff and soil loss in semi-arid Northern Ethiopia. Physical Geography, 34(3): 236-259.

Tayyebi A, Pijanowski B C, 2014. Modeling multiple land use changes using ANN, CART and MARS: Comparing tradeoffs in goodness of fit and explanatory power of data mining tools. Int. J. Appl. Earth Obs. Geoinf., 28: 102-116. doi: 10.1016/j.jag.2013.11.008.

Teka K, Van Rompaey A, Poesen J, 2013. Assessing the role of policies on land use change and agricultural development since 1960s in northern Ethiopia. Land Use Policy, 30(1): 944-951. doi: 10.1016/j.landusepol. 2012.07.005.

Teka K, Van Rompaey A, Poesen J et al., 2015. Spatial analysis of land cover changes in eastern Tigray (Ethiopia) from 1965 to 2007: Are there signs of a forest transition? Land Degrad. Dev., 26(7): 680-689. doi: $10.1002 / 1 \mathrm{dr} .2275$.

Tesfamichael G, De Smedt F, Miruts H et al., 2010. Large-scale geological mapping of the Geba basin, northern Ethiopia. Tigray Livelihood Paper No 9, VLIR - Mekelle University IUC Program, 46pp. Tesfaye C, Gebretsadik E, 1982. Hydrogeology of Mekelle Aea (ND37-11). Ministry of Mines and Energy, Ethiopian Institute of Geological Survey. The Provisional Military Government of Socialist Ethiopia. Memoir No.2, Addi Ababa, Ethiopia, pp50.

Tielens S, 2012. Towards a Soil Map of the Geba Catchment using benchmark soils. Dissertation, K.U. Leuven, Belgium, pp226.

Tilahun K, 2006. Analysis of rainfall climate and evapo-transpiration in arid and semi-arid regions of Ethiopia using data over the last half a century. J. Arid Environ., 64(3): 474-487. doi: 10.1016/j.jaridenv.2005.06.013.

Tsegaye D, Moe S R, Vedeld P et al., 2010. Land-use/cover dynamics in Northern Afar rangelands, Ethiopia. Agriculture, Ecosystems \& Environment, 139(1): 174-180.

Turner B, Meyer W B, Skole D L, 1994. Global land-use/land-cover change: Towards an integrated study. Ambio Stockholm, 23(1): 91-95.

USGS, 2016. Shuttle Radar Topography Mission (SRTM) (1-arc second) documentation. https://earthexplorer.usgs.gov/. Accessed 29/04/2016.

Van de Wauw J, Baert G, Moeyersons J et al., 2008. Soil-landscape relationships in the basalt-dominated highlands of Tigray, Ethiopia. Catena, 75(1): 117-127. doi: 10.1016/j.catena.2008.04.006.

Vancampenhout K, Nyssen J, Gebremichael D et al., 2006. Stone bunds for soil conservation in the northern Ethiopian Highlands: Impacts on soil fertility and crop yield. Soil and Tillage Research, 90(1): 1-15.

Vanmaercke M, Poesen J, Broeckx J et al., 2014. Sediment yield in Africa. Earth-Sci. Rev., 136: 350-368. doi: 10.1016/j.earscirev.2014.06.004.

Virgo K, Munro R, 1978. Soil and erosion features of the Central Plateau region of Tigrai, Ethiopia. Geoderma, 20(2): 131-157. doi: 10.1016/0016-7061(78)90040-X.

Woien H, 1995. Deforestation, information and citations. GeoJournal, 37(4): 501-511. doi: 10.1007/BF00806939.

WBISPP (Woody Biomass Inventory and Strategic Planning Project), 2003. Tigray Regional State: A strategic plan for the sustainable development, conservation, and management of the woody biomass resources. Final Report, Mekelle, Ethiopia.

Zeimetz K A, Dillon E, Hardy E E et al., 1976. Using area point samples and airphotos to estimate land use change. Agricultural Economics Research, 28(2): 65-74.

Zeleke G, Hurni H, 2001. Implications of land use and land cover dynamics for mountain resource degradation in the Northwestern Ethiopian Highlands. Mountain Research and Development, 21(2): 184-191. 


\section{Appendix}

Table S1 Keys used for the classification of LUC during the point counting on AP and GE

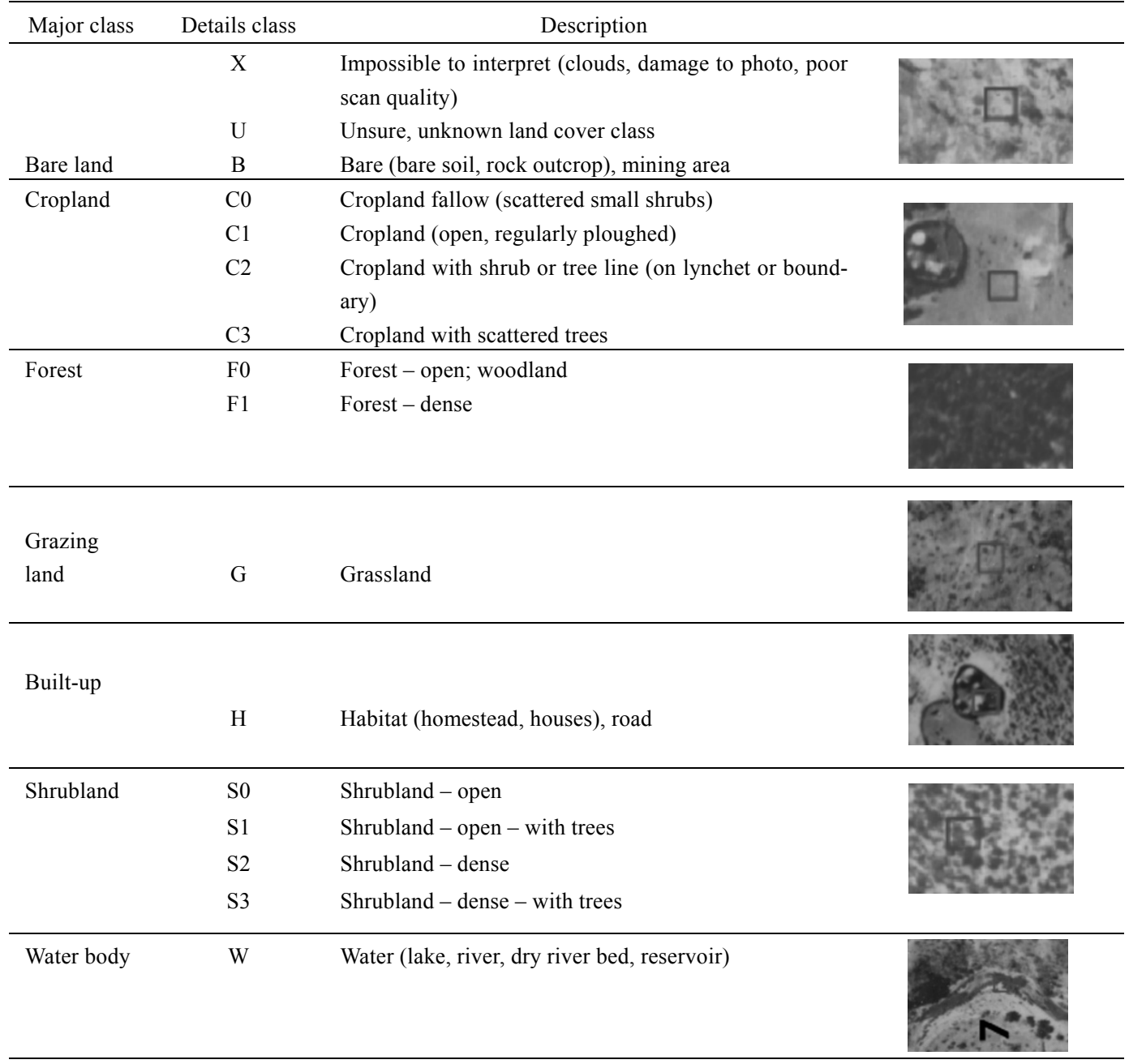

Table S2 Frequency and percentage of scene at which land use/cover types have shown different changes between the 1930s and 2014; Chi-square test result. $n=139$

\begin{tabular}{|c|c|c|c|c|c|c|c|}
\hline \multirow{2}{*}{$\begin{array}{c}\text { Land } \\
\text { use/cover }\end{array}$} & \multicolumn{2}{|c|}{ Increased } & \multicolumn{2}{|c|}{ Decreased } & \multicolumn{2}{|c|}{ No change } & \multirow{2}{*}{ Sig. } \\
\hline & Frequency & Percent & Frequency & Percent & Frequency & Percent & \\
\hline Bare land & 101 & 73 & 23 & 17 & 15 & 11 & $<0.001$ \\
\hline Built-up area & 113 & 81 & 17 & 12 & 9 & 6 & $<0.001$ \\
\hline Cropland & 85 & 61 & 52 & 37 & 2 & 1 & $<0.001$ \\
\hline Forest & 33 & 24 & 53 & 38 & 53 & 38 & 0.088 \\
\hline Grassland & 96 & 69 & 14 & 10 & 29 & 21 & $<0.001$ \\
\hline Shrubland & 29 & 21 & 105 & 76 & 5 & 4 & $<0.001$ \\
\hline Water body & 73 & 53 & 28 & 20 & 38 & 27 & $<0.001$ \\
\hline
\end{tabular}


Table S3 Equations of three major land use/cover (cropland, shrubland and forest) in the 1930s and 2014 which were developed by Multivariate Adaptive Regression Spline model. C1930s = cropland in the 1930s, C2014 = cropland in 2014, S1930s = shrubland in the 1930s, S2014 = shrubland in 2014, F1930s = forest in the 1930s and F2014= forest in 2014. $\mathrm{h}=$ hinge function with zero and a constant (knot) of a factor. For the explanation see Table 1.

\begin{tabular}{|c|c|c|}
\hline $\begin{array}{l}\text { Land } \\
\text { use/cover }\end{array}$ & $1930 \mathrm{~s}$ & 2014 \\
\hline Cropland & $\begin{array}{l}\mathrm{C} 1930 \mathrm{~s}= \\
0.2232 \\
-0.01063 * \mathrm{~h}(0, \mathrm{DT} 30 \mathrm{~s}-6) \\
+0.02519 * \mathrm{~h}(0,17.4-\mathrm{slope}) \\
-0.1589 * \mathrm{~h}(0, \mathrm{DT} 30 \mathrm{~s}-8) * \mathrm{SS} \\
+0.09218 * \mathrm{~h}(0,6-\mathrm{DT} 30 \mathrm{~s}) * \mathrm{SMS} \\
+0.04719 * \mathrm{~h}(0,7-\mathrm{slope}) * \mathrm{SS} \\
-0.00141 * \mathrm{~h}(0,2037-\mathrm{alt}) * \mathrm{SS} \\
+0.1724 * \mathrm{~h}(0, \mathrm{DT} 30 \mathrm{~s}-6) * \mathrm{SS} \\
\text { GCV } 0.041 \mathrm{RSS} 4.281 \quad \mathrm{GCV} R^{2} 0.53 R^{2} 0.64\end{array}$ & $\begin{array}{l}\mathrm{C} 2014= \\
0.1196 \\
+0.2177 * \mathrm{SS} \\
+0.0008321 * \mathrm{~h}(0, \text { alt }-1859) \\
+0.02293 * \mathrm{~h}(0,16-\text { slope }) \\
-0.000121 * \mathrm{Pd} * \mathrm{SS} \\
-0.0000118 * \mathrm{Pd} * \mathrm{~h}(0,16-\text { slope }) \\
+0.0005874 * \mathrm{~h}(0,1859-\text { alt }) * \mathrm{SMS} \\
-0.0000299 * \mathrm{~h}(0, \text { alt }-1859) * \mathrm{~h}(0, \text { slope }-7) \\
-0.0001047 * \mathrm{~h}(0, \text { alt }-2150) * \mathrm{~h}(0,16-\text { slope }) \\
\text { GCV } 0.028 \text { RSS } 2.78 \quad \text { GRSq } 0.63 \mathrm{R}^{2} 0.73\end{array}$ \\
\hline Shrubland & $\begin{array}{l}\mathrm{S} 1930 \mathrm{~s}= \\
0.6112 \\
+0.1556 * \mathrm{SNS} \\
-0.000357 * \mathrm{~h}(0, \text { alt }-1778) \\
-0.01745 * \mathrm{~h}(0,15.4-\text { slope })\end{array}$ & $\begin{array}{l}\mathrm{S} 2014= \\
0.6841 \\
-0.2899 * \mathrm{SS} \\
-0.1131 * \mathrm{SMS} \\
-0.0003771 * \mathrm{~h}(0,1778-\text { alt }) \\
-0.0002857 * \mathrm{~h}(0, \text { alt } 1-1859) \\
-0.02089 * \mathrm{~h}(0,14-\text { slope })\end{array}$ \\
\hline \multirow[t]{2}{*}{ Forest } & $\begin{array}{l}\text { GCV } 0.044 \text { RSS } 5.441 \text { GCV R } 0.38 \mathrm{R}^{2} 0.44 \\
\mathrm{~F} 1930 \mathrm{~s}= \\
0.06381 \\
+0.08914 * \mathrm{LSNC} \\
-0.0001301 * \mathrm{~h}(0,2361-\text { alt }) \\
+0.0001466 * \mathrm{~h}(0, \text { slope }-6) * \mathrm{~h}(0, \text { alt }-1980) \\
+0.0001778 * \mathrm{~h}(0, \text { slope }-6) * \mathrm{~h}(0,-2053) \\
+0.0001651 * \text { slope } * \max (0, \text { alt }-2361) * \mathrm{LSC} \\
+0.000121 * \mathrm{~h}(0, \text { slope }-6) * \mathrm{~h}(0, \text { alt }-1980) * \mathrm{SNS}\end{array}$ & $\begin{array}{l}\text { GCV } 0.027 \text { RSS } 3.16 \text { GCV R } 0.58 \quad \mathrm{R}^{2} 0.64 \\
\mathrm{~F} 2014= \\
0.006373 \\
-0.1273 * \mathrm{SS} \\
+0.0002263 * \mathrm{~h}(0, \text { alt }-1830) \\
+0.0003854 * \mathrm{~h}(0, \text { alt }-2396) * \mathrm{SNS} * \mathrm{LSC} \\
+0.02682 * \mathrm{~h}(0, \text { alt }-2396) * \mathrm{LSC} \\
+0.000000614 * \mathrm{~h}(0,2396-\text { alt }) * \mathrm{~h}(0, \mathrm{Pd}-81)\end{array}$ \\
\hline & GCV 0.012 RSS $1.276 \quad$ GCV R $^{2} 0.40 \quad \mathrm{R}^{2} 0.52$ & $\mathrm{GCV} \mathrm{R}^{2} 0.31 \mathrm{R}^{2} 0.47$ \\
\hline
\end{tabular}

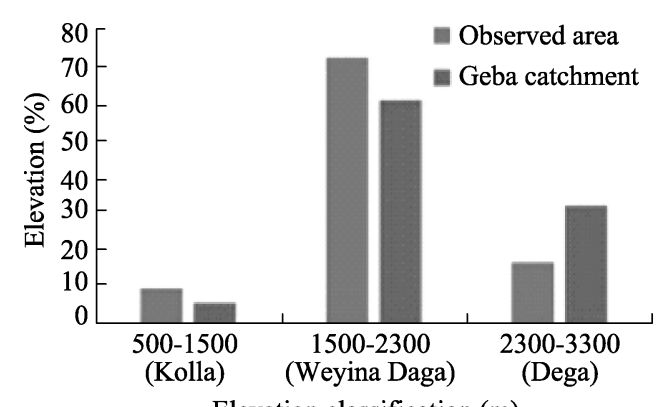

Elevation classification (m)

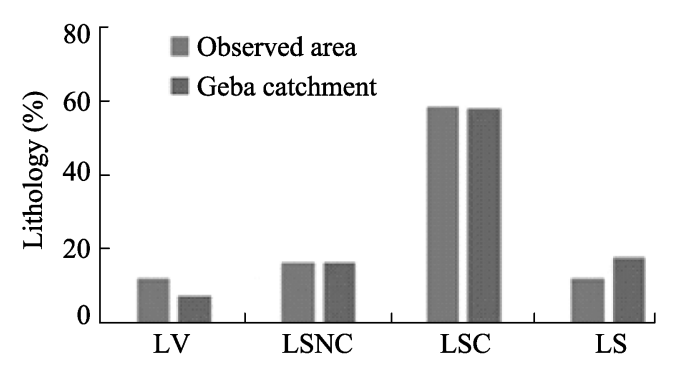

Lithology classification

Figure S1 Proportion of elevation (classified based on traditional agro-ecology) and lithology for the observed and predicted map. For explanation on variables see Table 1. 

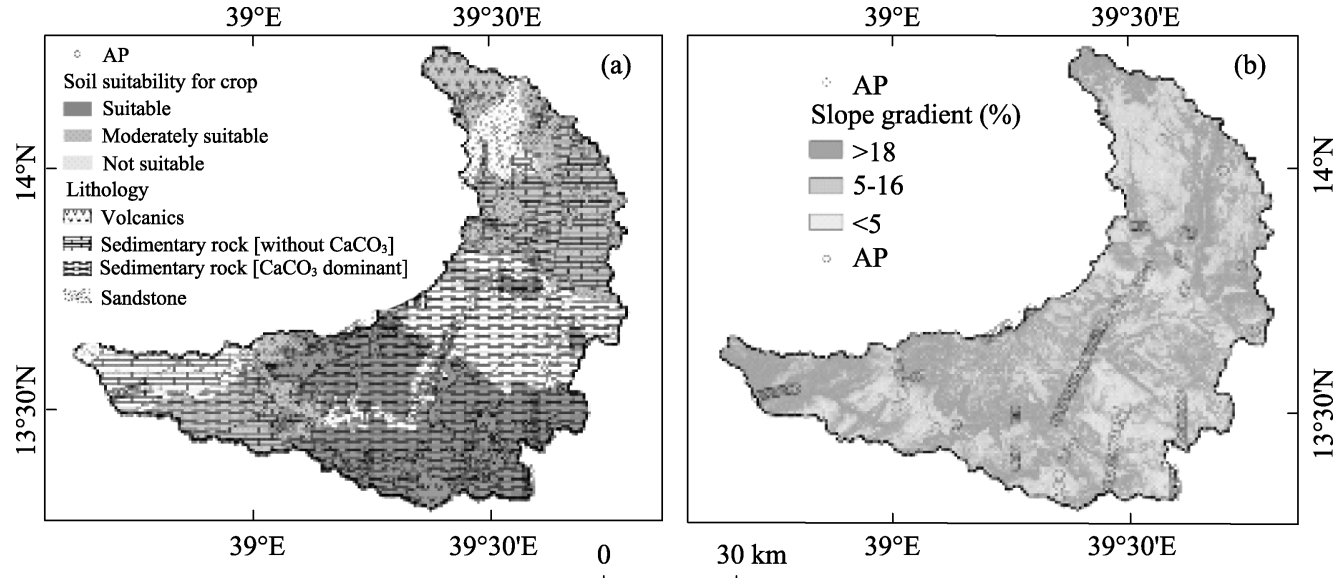

Figure S2 Geba catchment showing: a) lithology (extracted from Tesfamichael et al., 2010; Tesfaye and Gebretsadik, 1982) and soil suitability for cultivation (based on Tielens, 2012); b) slope gradient extracted from DEM - SRTM (USGS, 2014). AP: Location of Italian aerial photo
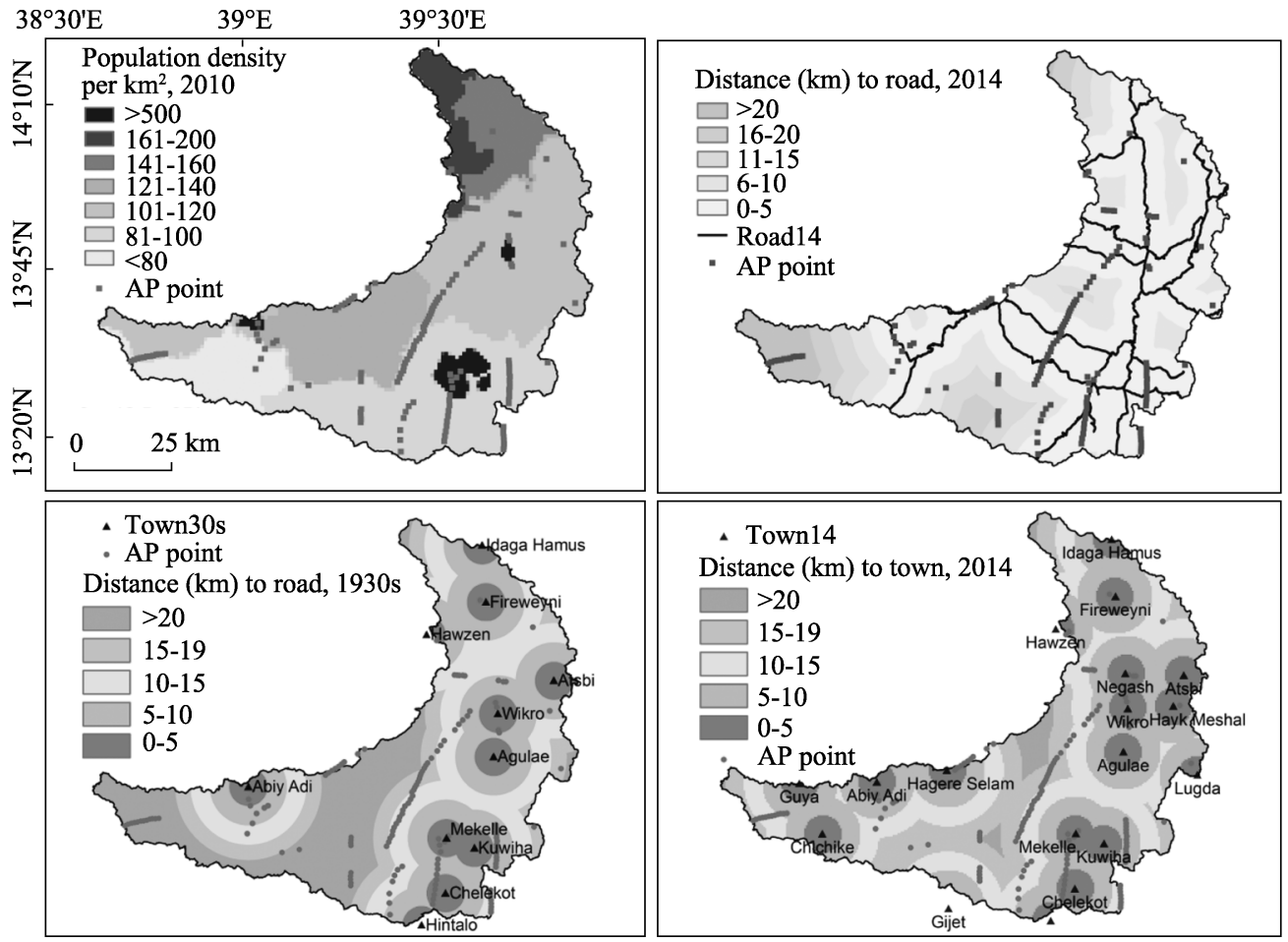

Figure S3 Maps of socio-economic variables 


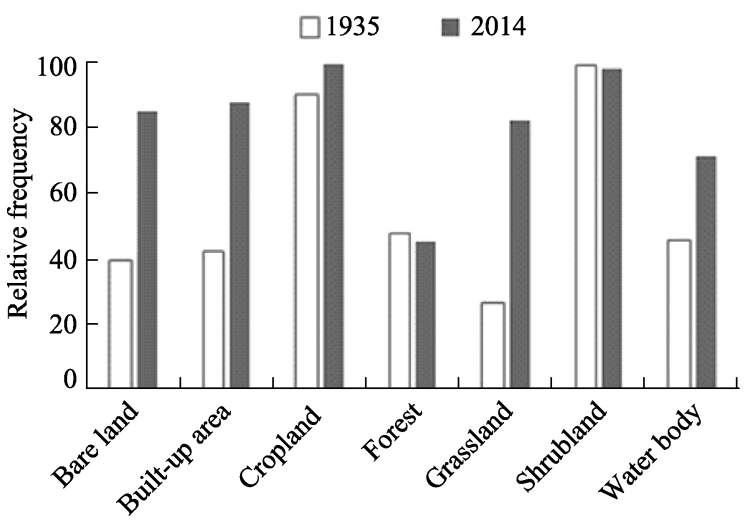

Figure S4 Frequency of occurrence (absence or presence) of different land use/cover types in the 1930s and 2014 scenes, $\mathrm{n}=139$ 